\title{
Authigenic carbonate mounds from active methane seeps on the southern Aquitaine Shelf (Bay of Biscay, France): evidence for anaerobic oxidation of biogenic methane and submarine groundwater discharge during formation
}

\author{
Pierre Catherine ${ }^{1,{ }^{*}}$, Demange Jérome ${ }^{1}$, Blanc-Valleron Marie-Madeleine ${ }^{2}$, Dupré Stéphanie ${ }^{3}$
}

${ }^{1}$ UPMC-Sorbonne Universités, LOCEAN, 4 place Jussieu, 75252 Parix Cedex 05, France

${ }^{2}$ MNHN-Sorbonne Universités, CR2P, 57 rue Cuvier, 75005 Paris, France

${ }^{3}$ IFREMER, Unité Géosciences Marines, BP 70, 29280 Plouzané-Cedex, France

${ }^{*}$ Corresponding author : Catherine Pierre, email address : $\underline{\text { catherine.pierre@locean-ipsl.upmc.fr }}$

\begin{abstract}
:
The widespread methane emissions that were discovered in 2013 on the Aquitaine Shelf at water depth between 140 and $220 \mathrm{~m}$ are associated with authigenic carbonate crusts that cover meter-high subcircular reliefs of 10 to $100 \mathrm{~m}$ in diameter. These authigenic carbonates are primarily aragonite plus calcite and dolomite, which cement the fine- to medium-grained sandy sediment. The carbonate cement is often pierced by numerous circular cavities of 5 to $10 \mu \mathrm{m}$ in diameter that are considered to be moulds of gas bubbles. Conversely, micron-sized cavities in the aragonite crystals are attributed to dissolution features, in relation to the production of $\mathrm{CO} 2$ during the aerobic oxidation of methane. The oxygen isotopic compositions of bulk carbonate $(+1.7$ to $+3.7 \% 0)$ and aragonite cements obtained from microsampling $(-0.1$ to $+1.4 \%)$ indicate that these carbonates were precipitated in mixtures of seawater and freshwater, i.e., in the context of submarine groundwater discharge at the seafloor. The carbon isotopic compositions of authigenic carbonates (-51.9 to $38.1 \%$ ) and of aragonite cements $(-49.9$ to $-29.3 \%$ ) show that the dissolved inorganic carbon of pore fluids was mostly produced by the anaerobic oxidation of biogenic methane and also partly from the groundwater system.
\end{abstract}

\section{Highlights}

- Authigenic carbonate crusts are related to methane seeps on the Aquitaine Shelf. Anaerobic oxidation of methane was responsible for carbonate cementation. S Submarine groundwater discharge is mixed with seawater recharge at the shelf break.

Keywords : Aquitaine Shelf, methane-derived authigenic carbonates, oxygen isotopes, carbon isotopes, submarine groundwater discharge, anaerobic oxidation of methane, aerobic oxidation of methane 


\section{1- Introduction}

Authigenic carbonates derived from the anaerobic oxidation of methane (AOM) have been extensively described in many examples of present and past cold seep environments at passive and active continental margins (e.g., Aloisi et al., 2000; Naehr et al., 2000; Peckmann et al., 2001; Judd and Hovland, 2007; Foucher et al., 2009; Crémière et al., 2012; Bayon et al., 2013; Dupré et al., 2014c; Pierre et al., 2014a,b). These studies demonstrated that in cold seep environments, carbonate formation was driven by the activity of a microbial consortium of sulphate-reducing bacteria and methanotrophic archea where sulphate was reduced to sulphide and methane was oxidized as bicarbonate (Boetius et al., 2000), thus increasing considerably the dissolved inorganic carbon (DIC) concentration in water where carbonate minerals may reach saturation and precipitate. Therefore methane-derived authigenic carbonates (MDAC) would precipitate within the sulphate-methane transition zone (SMTZ), that corresponds to an oxic-anoxic boundary lying generally below the seafloor at various depth within the sediment but sometimes in the anoxic bottom waters as it is the case in the Black Sea (Peckmann et al., 2001). The chemical composition of fluids where AOM is active typically displays very high DIC concentrations (up to 10 times the sea water concentration, and even more), which is prerequisite for carbonate minerals oversaturation (Claypool and Threlkeld, 1974; Wehrmann et al., 2011). The carbon isotopic composition of MDAC that is derived from ${ }^{13} \mathrm{C}$-depleted methane represents the best tracer of the origin of the DIC source.

The present study is focused on the mineralogical and oxygen and carbon stable isotopes characterization of the authigenic carbonates associated with the active methane seeps that were recently discovered on the southern Aquitaine Shelf. Specific objectives of this study include: (1) the characterization of the biogeochemical processes responsible for their formation; (2) the understanding of the relation between seeping fluids and authigenic carbonates; (3) the elaboration of a conceptual scenario of their environment of formation. These objectives would help to identify the sources of water (marine, continental) and of 


\section{ACCEPTED MANUSCRIPT}

DIC (anaerobic and aerobic oxidation of methane, fresh-water aquifer) in this shallow marine setting where seepage of methane-rich fluids to the seafloor might have been active for a long time.

\section{2- Geological setting}

The Aquitaine Shelf represents a gently deepening continental platform that extends from the Gironde river estuary $\left(45^{\circ} 45^{\prime} \mathrm{N}\right)$ to the Capbreton Canyon $\left(43^{\circ} 34^{\prime} \mathrm{N}\right)$ (Fig. 1). The upper sedimentary unit (maximum 2 m thick) was deposited recently during the upper Holocene when the sea level was stabilized close to the present one (Cirac et al., 2000). It is overlying the soft sediment cover made up by six seismic units deposited during the Pleistocene; individual sequence comprises two sub-units deposited during stable sea level lowstand and transgressive phase respectively, the boundaries of which correspond to erosion surfaces during periods when sea level drops (Bellec and Cirac, 2010).

Numerous gas emissions in the water column and seabed structures were discovered by multibeam data acquired for fish resource estimations on the southern part of the Aquitaine Shelf $\left(44^{\circ} 35^{\prime} \mathrm{N}\right.$ to $\left.43^{\circ} 50^{\prime} \mathrm{N}\right)$ at shallow depths from 140 to $185 \mathrm{~m}$, about 50 to $60 \mathrm{~km}$ away from the present-day coastline (Dupré et al., 2014a). Two French oceanographic cruises Gazcogne1 (July-August 2013) and Gazcogne2 (September 2013) were dedicated to the specific study of this area. During the Gazcognel cruise, 9200 seabed structures were identified by acoustic imagery and mapped precisely by swath bathymetry (Dupré et al., 2014b). The Gazcogne2 cruise was dedicated to Remote Operated Vehicle (ROV) observations and sampling of three selected seabed structures (A, D and G) corresponding to highly active seeping sites (Fig. 1). The morphology of the seabed structures corresponds to subcircular, discontinuous mounds about one meter high and 10 to 100 meters in diameter that are partly covered by carbonate crusts, and surrounded by fine-grained, sandy, silty seafloor sediments. The carbonate mounds are associated with more or less active seeps identified by acoustic gas flares in the water column, that cover a wide area of more than $200 \mathrm{~km}^{2}$ extending by $\sim 80 \mathrm{~km}$ from north to south and $5 \mathrm{~km}$ on average from west to east at depths from 140 to $220 \mathrm{~m}$ (Dupré et al., 2014b) that is thus much wider than it was previously described (Dupré et al., 2014a). 


\section{ACCEPTED MANUSCRIPT}

These occurrences are limited to the western edge of the Aquitaine Shelf and they display no spatial organization and no obvious relation with the deep regional structures (Dupré et al., 2014a).

\section{3- Material and methods}

\section{3-1 Sedimentary sampling}

During the Gazcogne1 cruise the sediment sampling was realized with box-corer that allowed recovering 20 to $30 \mathrm{~cm}$ of the upper sediment made of homogenous siltysands; 15 samples of silty-sands were collected in eight box cores retrieved between 151 and $273 \mathrm{~m}$ of water depth (Table 1, Fig. 1). Three box-cores [GZ1-BH-21, GZ1-BH-23, GZ1-BH-24] retrieved between 160 and $175 \mathrm{~m}$ of water depth (Table 1, Fig. 1) contained small pieces of carbonate sandstone, which is likely derived from buried carbonate crusts that were broken during coring.

The Gazcogne2 cruise was designed as a multidisciplinary study of selected seep targets. Three dives of the Victor 6000-ROV provided observations and sampling of the fluids escaping from the sediments at the seafloor, of the authigenic carbonates and of the microbial and megafauna ecosystems (Dupré et al., 2014b). The 15 authigenic carbonate samples (11 seafloor crusts and 4 concretions from the subseafloor sediments) were lying between 156 and $182 \mathrm{~m}$ of water depth (Table 1, Fig. 1, 2).

Prior to the mineralogical and isotopic analyses, a few grams of each sample was rinsed with ultra-pure water to eliminate salt, dried in an oven at $60^{\circ} \mathrm{C}$ during $24 \mathrm{~h}$, and grounded in an agate mortar to obtain a homogenous powder of the bulk sediment. For 6 samples where the white crystalline carbonate cement was evidenced by binocular microscope observations, selective microsampling of the cement was made by dental drilling.

\section{3-2 Mineralogy}

The total carbonate content of bulk sediment (in weight $\%$ of dry sediment, wt $\%$ ) was measured by reacting $100 \mathrm{mg}$ of the powdered sediment with $1 \mathrm{ml}$ of $\mathrm{HCl}-8 \mathrm{~N}$ in a manual calcimeter. The precision of the measurement is better than $1 \%$ for the carbonate-rich samples. 


\section{ACCEPTED MANUSCRIPT}

The mineralogy of bulk sediment was determined by X-ray diffraction (XRD) of nonoriented powder, using a diffractometer (Brüker D2 Phaser) equipped with a Lynxeye detector, $\mathrm{Cu}-\mathrm{k} \alpha$ radiation $(\lambda=0.15406 \AA)$ and $\mathrm{Ni}$ filter at $30 \mathrm{kV}$ and $10 \mathrm{~mA}$. The position of the major diffraction peak $\left(\mathrm{d}_{104}\right)$ of calcite was used to estimate the relative mole $\%$ content of $\mathrm{MgCO}_{3}$ in the crystal lattice (Goldsmith et al., 1961).

Scanning electron microscope (SEM) observations and elemental analyses by dispersive energy X-ray spectrometer were conducted on most samples of carbonate crusts and concretions to observe crystal morphologies and the structural relations between the different mineral components.

\section{3-3 Oxygen and carbon stable isotopes}

The oxygen and carbon isotopic compositions of carbonate are expressed in the conventional $\delta$ notation, which corresponds to the relative difference in parts per mille (\%o) between the isotopic ratio $\mathrm{R}\left({ }^{18} \mathrm{O} /{ }^{16} \mathrm{C}\right.$ and $\left.{ }^{13} \mathrm{C} /{ }^{12} \mathrm{C}\right)$ of the sample (s) and of the reference $(\mathrm{r})$ VPDB (Vienna Peedee Belemnitella) defined by Craig (1965) and revised by Gonfiantini et al. (1995).

$$
\delta=[(\mathrm{Rs} / \mathrm{Rr})-1] \times 1000
$$

The isotopic measurements were realized on the bulk sediment powder (100 to $200 \mathrm{mg}$ for the carbonate crusts depending on their carbonate content, and $1 \mathrm{~g}$ for the silty-sand sediments) that was reacted at $25^{\circ} \mathrm{C}$ during one day with $100 \%$ phosphoric acid; the $\mathrm{CO}_{2}$ produced by the reaction was extracted offline and analysed with a dual inlet-triple collector isotopic ratio mass spectrometer (VG-Sira 9). For the carbonate cement microsamples, about $100 \mu \mathrm{g}$ were reacted online with the multicarb coupled with the mass spectrometer (VG-Isoprime). The analytical precision of the mass spectrometer $2 \sigma$ is $0.01 \%$ and the reproducibility for repeated measurements of the laboratory reference calcite (Carrara marble) is $\pm 0.05 \%$ for both $\delta^{18} \mathrm{O}$ and $\delta^{13} \mathrm{C}$ values.

\section{4- Results}

The analytical results of mineralogy and stable isotopes of the soft sediments and carbonate crusts and concretions sampled during the cruises Gazcogne1 and Gazcogne2 are listed in Table 1. 


\section{ACCEPTED MANUSCRIPT}

4-1 Petrography and mineralogy

The soft sediments are medium-grey fine- to medium-grained silty-sands where the siliciclastic minerals comprise quartz, feldspars, amphiboles, micas and clay minerals. The carbonate fraction is relatively low ( 7 to $15 \mathrm{wt} \%$ ) and represented by low magnesian calcite (0.3 to $1.3 \mathrm{~mole} \% \mathrm{MgCO}_{3}$ ) from fragments of bivalve shells, foraminifers, coccoliths and sponge spicules.

The carbonate crusts and concretions are made by the seafloor sediment, which is cemented by carbonate, yielding hard porous sandstone. The surface of the crusts is colonized by numerous non-chemosynthetic organisms (bivalves mostly represented by Neopycnodonte, sponges, serpulids) and strongly impregnated by manganese and iron oxihydroxides as shown by their brownish to black coloration (Fig. 3 to 5). The total carbonate content ( 35 to $52 \mathrm{wt} \%$ ) is made by mixtures in variable proportions of calcite, aragonite and dolomite (Fig. 6); it is dominated by aragonite that makes up to more than $75 \%$ of the carbonate fraction, indicating that this mineral constitutes the authigenic carbonate cement for the majority of carbonate crusts. In all crusts and concretions, calcite has generally a low magnesian composition ( 0.3 to 1.3 mole $\left.\% \mathrm{MgCO}_{3}\right)$ similar to that of the carbonate components of the soft sediments, although authigenic Mg-rich calcite may be associated with the sedimentary calcite as in the concretion GZ2-535-CL12-3/5 cm. A few crusts and concretions contain also significant amount of dolomite (6 to $9 \%$ of the carbonate fraction) associated with aragonite. The crust GZ2-537-CC2 contains much less aragonite and the authigenic carbonate cement is dominated by dolomite, which composition is non-stoichiometric and estimated to be calcium-rich based on the diffraction peak position $\left(\mathrm{d}_{104}=2.902 \AA\right)$ and the SEM EDAX analysis. Other authigenic minerals such as pyrite and goethite are present in trace amounts and were also identified by XRD in a few samples.

The SEM observations of the carbonate crusts show that authigenic aragonite occurs as acicular to prismatic crystals that develop radiating sheaves and palisades (Fig. 7A-B) filling voids and cementing detrital grains and biogenic elements. From a general point of view, the porosity appears very important because in most samples the aragonite cements show numerous circular holes of about $10 \mu \mathrm{m}$ in diameter (Fig. 7B-C). Moreover, in a few samples, the aragonite crystals display also micron-sized cavities of dissolution (Fig. 8B). Authigenic calcite occurs as aggregates of sub-rhombohedral tiny crystals that are growing 


\section{ACCEPTED MANUSCRIPT}

within the residual porosity of the aragonite framework (Fig. 8D), clearly indicating that calcite precipitation post-dates that of aragonite. Authigenic dolomite exhibits crystal habits either similar to those of calcite described above or platy (Fig. 8C); they frequently occur as overgrowths on the aragonite crystals and fill-in the residual porosity, which testify that their formation also post-dates that of aragonite. Pyrite is present as framboids and isolated grains disseminated within the carbonate cement (Fig. 8A) but it is often replaced by goethite or by an $\mathrm{Fe}-\mathrm{Al}$ phosphate. Authigenic barite is more rarely present as tiny needle shape crystals either isolated or grouped as rosettes.

4-2 Oxygen and carbon isotope compositions of carbonates

The $\delta^{18} \mathrm{O}$ and $\delta^{13} \mathrm{C}$ values of the bulk carbonate of sediments (Table 1) vary in relatively narrow ranges: $-2.7<\delta^{18} \mathrm{O} \%$ VPDB $<0.0 ;-1.0<\delta^{13} \mathrm{C} \%$ VPDB $<+0.4$. Higher values $\left(\delta^{18} \mathrm{O}=+2.1 \%\right.$; $\delta^{13} \mathrm{C}=+0.8 \%$ ) were measured in bivalve shells from the sample GZ1-BU-11, 22-23 cm.

The carbonate crusts and concretions display very different and wider ranges of variations (Table 1, Fig. 9). For the bulk carbonate, the $\delta^{18} \mathrm{O}$ and $\delta^{13} \mathrm{C}$ values vary in the ranges of +1.7 to $+4.5 \%$ and -51.9 to $-38.1 \%$ respectively. The highest $\delta^{18} \mathrm{O}$ value was measured in the crust (GZ2-537-CC02) with high dolomitic cement. The isotopic compositions of the aragonitic cements obtained by microsampling show significantly lower $\delta^{18} \mathrm{O}$ values $\left(-0.1\right.$ to $+1.4 \%$ ) but slightly higher $\delta^{13} \mathrm{C}$ values $(-49.9$ to $-29.3 \%$ ) than those of the bulk carbonate (Fig. 9).

\section{5- Discussion}

5-1 Mineralogy and growth rates of carbonate crusts of methane seeps of the Aquitaine Shelf

The mineralogy of MDAC cements of carbonate crusts in cold seep environments is highly dependent both of the physico-chemical conditions (temperature, $\mathrm{pCO}_{2}$, alkalinity, sulphate concentration, $\mathrm{Mg} / \mathrm{Ca}$ ratio) of pore fluids (Morse et al., 1997, De ChoudensSanchez and Gonzalez, 2009, Balthasar and Cusack, 2015) and of the methane flux that controls the AOM rate and the carbonate precipitation in the sulphate-methane transition zone (Nöthen and Kasten, 2011). The carbonate mineral composition would thus be considered as the record of pore water chemistry. Aragonite is generally associated with 


\section{ACCEPTED MANUSCRIPT}

high temperature, high sulphate concentration, high $\mathrm{Mg} / \mathrm{Ca}$ ratio and high methane flux supporting high AOM rate whereas the reverse conditions promote calcite precipitation. The two calcium carbonate mineral polymorphs, aragonite and calcite, may be present either as a single mineral or as mixtures in variable proportions. Dolomite may also be associated with aragonite and calcite as a minor constituent in the subsurface crusts but it often becomes the major carbonate component of the crusts and concretions that are present deeper in the sedimentary deposits, generally below the SMTZ where pore waters are depleted in sulphate.

The carbonate crusts of the Aquitaine Shelf are dominated by aragonite, which is in good agreement with the relatively warm bottom water temperature $\left(12^{\circ} \mathrm{C}\right.$ in average for the present time) and with the vigorous methane flux presently escaping at the seafloor (Ruffine et al., 2014). The strength of methane flux is also shown by the numerous rounded cavities observed with SEM where the aragonite crystals constitute the external mould of the cavities that are interpreted as traces of gas (methane) bubbles. The cavities of the carbonate crusts of the Aquitaine Shelf are very different by their size $(10 \mu \mathrm{m})$ and shape (circular) from the large (a few $\mathrm{mm}$ ) and irregular voids of carbonate crusts from the eastern Mediterranean Sea that were attributed to corrosion due to aerobic oxidation of methane at the seafloor (Himmler et al., 2011). The associated calcite might indicate precipitation of this authigenic mineral at lower bottom water temperature and/or lower methane flux. The SEM observations have revealed that authigenic calcite and dolomite were often precipitated after aragonite in the residual porosity, indicating possibly that composition of pore solutions would have changed through time.

Following the numerical modelling results of Luff et al. (2004) the formation of a carbonate crust would require fluids with methane concentrations higher than $50 \mathrm{mmol} \mathrm{l}^{-1}$ and upward advection rates lower than $90 \mathrm{~cm} / \mathrm{yr}$; high sedimentation rates $(>0.5 \mathrm{~mm} / \mathrm{yr})$ would inhibit carbonate crust formation whereas low bioturbation rates $\left(<0.05 \mathrm{~cm}^{2} / \mathrm{yr}\right)$ would lead to carbonate dissolution by aerobic oxidation of methane (AeOM); conversely high bioirrigation activity from benthic organisms would increase the carbonate crust formation by supplying sulphate-rich bottom seawater deeper in the sediment and thus enhancing AOM. The U/Th dating of carbonate crusts has provided estimations of their growth rate of the order of $\mathrm{cm} / \mathrm{k.y}$. in eastern Mediterranean (Bayon et al., 2009, 2013) but it was 3 times higher at Hydrate Ridge on the Cascadian Margin (Teichert et al., 2003) and 


\section{ACCEPTED MANUSCRIPT}

reached more than one m/ k.y.. at the Hikurangi Margin in New Zealand (Liebetrau et al., 2010).

Although dating the carbonate crusts of the Aquitaine Shelf is not yet done, their thickness $(5$ to $30 \mathrm{~cm}$ ) and assuming a growth rate from $\mathrm{cm} / \mathrm{k} . \mathrm{y}$. to $\mathrm{m} / \mathrm{k} . \mathrm{y}$ would indicate that the time spanned for their formation was from a few tens of thousands of years to less than a century. This means that their growth would have started either during the last glacial period or during relatively recent times. Notably, oceanic conditions during the carbonate crust formation because they were different during the Last Glacial Maximum (LGM) 20,000 years ago differed substantially from those observed today: the global mean sea level was lower by $120 \mathrm{~m}$, the bottom sea water temperatures of the North Atlantic were in average lower by $4^{\circ} \mathrm{C}$, the $\delta^{18} \mathrm{O}$ values of the global ocean water were higher by $1.2 \%$ due to the increase of ${ }^{18} \mathrm{O}$-depleted ice-sheets of the Northern hemisphere (Waelbroeck et al., 2002, Peltier and Fairbanks, 2006). These variations of glacial ocean conditions would thus result in a positive shift by at least $2.2 \%$ of the $\delta^{18} \mathrm{O}$ values of carbonates precipitated at the seafloor. Moreover, the maximum sea level fall during the LGM would have shifted the shoreline westwards, which was then only 10 to $20 \mathrm{~km}$ eastwards from the present-day seeping sites and the water depths there were very shallow at 20 to $100 \mathrm{~m}$.

\section{5-2 Estimation of the authigenic carbonate fraction of the carbonate crusts}

The carbonate crusts contain sedimentary calcite (coccoliths, foraminifers, shell fragments, detrital carbonate) and other detrital siliciclastic elements that are cemented by the authigenic carbonate. The $\delta^{18} \mathrm{O}$ and $\delta^{13} \mathrm{C}$ values of the pure MDAC fraction $\mathrm{f}$ may be calculated using a simple mass-balance equation.

$$
\delta_{\text {crust }}=\mathrm{fx}\left(\delta_{\mathrm{MDAC}}\right)+(1-\mathrm{f}) \mathrm{x}\left(\delta_{\text {sediment }}\right)
$$

The carbonate fraction of sediment represents $12 \mathrm{wt} \%$ in average (Table 1). The isotopic compositions of the sedimentary carbonate $\left(\delta^{18} \mathrm{O}=-1.5 \% \mathrm{~m} \pm 0.7 \% 0, \delta^{13} \mathrm{C}=-0.3 \%\right.$ $\pm 0.4 \%$ o $)$ used for the calculation from equation (2) are derived from the $\delta$ values of the bulk carbonate fraction of the sediments (Table 1). The estimations of the $\delta^{18} \mathrm{O}$ and $\delta^{13} \mathrm{C}$ values of the MDAC fraction of the carbonate crusts are reported in Table 2; their ranges $(+3.3<$ $\delta^{18} \mathrm{O} \%$ VPDB $<+5.7 ;-71.6<\delta^{13} \mathrm{C} \%$ VPDB $\left.<-51.6\right)$ are shifted to higher $\delta^{18} \mathrm{O}$ values and lower $\delta^{13} \mathrm{C}$ values compared to those of the bulk carbonate. These estimated $\delta$ values 


\section{ACCEPTED MANUSCRIPT}

of MDAC would be more appropriate to characterize the composition of the fluids from which they precipitated.

5-3 Characterization of the oxygen isotopic composition of the sedimentary and diagenetic fluids

The oxygen isotopic composition of a carbonate depends on the temperature of precipitation and on the oxygen isotopic composition of water from which the carbonate precipitates. Moreover, the carbonate-water isotopic fractionation factor $\alpha$ depends on the carbonate mineralogy. By using the isotopic equilibrium equations, it is possible to calculate the theoretical values of a carbonate (calcite, aragonite, dolomite) that would precipitate at isotopic equilibrium with its environmental conditions (Table 2).

For the calcite-water isotopic equilibrium (Kim and O'Neil, 1997) with a correction of $+0.06 \%$ per mole $\% \mathrm{MgCO}_{3}$ (Tarutani et al., 1969) the temperature $\mathrm{T}$ is in degree Kelvin.

$$
1,000 \ln \alpha^{18} \mathrm{O} \text { calcite-water }=18.03 \times 10^{3} \mathrm{~T}^{-1}-32.42(3)
$$

For the aragonite-water isotopic equilibrium (Grossman and $\mathrm{Ku}, 1986)$ the $\delta^{18} \mathrm{O}$ values of aragonite and water are expressed in the VPDB and VSMOW scales respectively and the temperature $\left(\mathrm{t}^{\circ} \mathrm{C}\right)$ is in degree Celsius.

$$
\mathrm{t}^{\circ} \mathrm{C}=20.86-4.69 \times\left(\delta^{18} \mathrm{O} \text { aragonite }-\delta^{18} \mathrm{O} \text { water }\right)(4)
$$

For the dolomite-water isotopic equilibrium (Fritz and Smith, 1970) the temperature T is in degree Kelvin.

$1,000 \ln \alpha^{18} \mathrm{O}$ dolomite-water $=2.62 \times 10^{6} \mathrm{~T}^{-2}+2.17(5)$

The calcite-water equation (3) may also be used to estimate the equilibrium $\delta^{18} \mathrm{O}$ value of the biogenic calcite from the planktonic foraminifers and coccoliths living in the present-day or the LGM sea surface waters of the Aquitaine Shelf (average values: present day: $\mathrm{t} \sim 18^{\circ} \mathrm{C} ; \delta^{18} \mathrm{O} \sim+0.8 \%$ VSMOW; LGM: $\mathrm{t} \sim 14^{\circ} \mathrm{C} ; \delta^{18} \mathrm{O} \sim+2.0 \%$ VSMOW). The calculated $\delta^{18} \mathrm{O}$ values (present day $\sim 0 \%$; LGM $\sim+2 \%$ ) for this biogenic calcite are significantly higher than most values measured in the bulk carbonate fraction of the soft sediments (Table 2). This observation indicates that detrital carbonates probably make up variable contributions to the carbonate fraction of the soft sediments of the Aquitaine Shelf, 


\section{ACCEPTED MANUSCRIPT}

a result that is consistent with the context of huge detrital inputs on the Aquitaine Shelf (Bellec and Cirac, 2010).

The authigenic carbonate crusts and concretions were formed close to the seafloor of the Aquitaine Shelf where the present-day bottom water has an average temperature of $12^{\circ} \mathrm{C}$ and a $\delta^{18} \mathrm{O}$ value of about $+0.5 \%$ VSMOW. The estimations of $\delta^{18} \mathrm{O}$ values of calcite, aragonite and dolomite precipitated in isotopic equilibrium with this bottom water (using equations 3,4 and 5) are $+1.8 \%$, $+2.9 \%$ and $+4.5 \%$ respectively. The equilibrium $\delta^{18} \mathrm{O}$ values would be higher by about $2 \%$ for authigenic carbonate precipitation during LGM due to lower temperature and higher $\delta^{18} \mathrm{O}$ value of bottom seawater. Most carbonate crusts displaying $\delta^{18} \mathrm{O}$ values of the MDAC close to these equilibrium values would have thus precipitated under conditions similar to the present-day or LGM ones. However, most crusts, especially their aragonitic cement, have $\delta^{18} \mathrm{O}$ values much lower by a few \%o than those expected at isotopic equilibrium. If the maximum decrease by $2.6 \%$ in aragonite cement was explained by a temperature effect, it would correspond to a maximum increase by $10^{\circ} \mathrm{C}$, which would require seepage of warm fluids, an unrealistic scenario in the geological context of the Aquitaine Basin where the present-day thermal gradient is $29^{\circ} \mathrm{C} / \mathrm{km}$ (Biteau et al., 2006). Alternatively, these low $\delta^{18} \mathrm{O}$ values might record precipitation of carbonate cements in mixtures of seawater and ${ }^{18} \mathrm{O}$-depleted meteoric water. Such type of system of submarine groundwater discharge is well known on wide continental shelfs (e.g., Moore 1999, Burnett et al. 2003), as in the New Jersey margin where deep multilayered freshwater aquifers are present at more than $400 \mathrm{~m}$ depth below the seafloor and extend up to $150 \mathrm{~km}$ offshore (Hathaway et al., 1979, Malone et al., 2002, van Geldern et al., 2013).

\section{5-4 Characterization of the carbon sources}

In organic and methane-rich environments, the biogeochemical processes related to the anaerobic microbial activity produce bicarbonate ions, which increase DIC concentrations in pore waters and thus control the precipitation of authigenic carbonates.

$$
\begin{aligned}
& \mathrm{SO}_{4}{ }^{2-}+2 \mathrm{CH}_{2} \mathrm{O}->\mathrm{HS}^{-}+\mathrm{H}^{+}+2 \mathrm{HCO}_{3}{ }^{-}(6) \\
& \mathrm{SO}_{4}{ }^{2-}+\mathrm{CH}_{4}->\mathrm{HS}^{-}+\mathrm{HCO}_{3}{ }^{-}+\mathrm{H}_{2} \mathrm{O}(7)
\end{aligned}
$$

The stoichiometry of these reactions show that two moles of bicarbonate are produced during the bacterial reduction (BR) of one mole of sulphate (reaction 6) whereas one mole 


\section{ACCEPTED MANUSCRIPT}

of bicarbonate is produced during the anaerobic oxidation of methane (AOM) coupled with the reduction of one mole of sulphate (reaction 7). These reactions occur in strict anoxic conditions, where the sulphate ions are the limiting factor since they must be always present, even at very low concentrations, for promoting the BR and AOM reactions. The hydrogen sulphide, which is the by-product of these reactions, may be used either as an energy source by chemosynthetic organisms living at the seeping sites or they may precipitate as metallic sulphides, mostly iron sulphides (greigite, pyrite) in association with the authigenic carbonates.

The carbon isotopic compositions of the two substrates used during reactions (equation 6) and (equation 7) are very different, $-25 \%$ in average for marine organic matter, and from 110 to $-40 \%$ for bacterial and thermogenic methane respectively (Whiticar, 1999). The $\delta^{13} \mathrm{C}$ values of the bicarbonate produced during these reactions, and thus of the authigenic carbonate precipitated from pore waters DIC, would thus characterize the source of carbon used by the different pathways of sulphate reduction.

The $\delta^{13} \mathrm{C}$ values of the methane transported by the fluids on the Aquitaine Shelf can be deduced from the $\delta^{13} \mathrm{C}$ values of the MDAC by considering the carbon isotopic fractionation factors during AOM $\left(1.002<\alpha^{13} \mathrm{C}_{\mathrm{CH} 4-\mathrm{CO} 2}<1.014\right.$; Whiticar and Faber, 1986; Alperin et al., 1988) and during the precipitation of carbonate $\left(\varepsilon^{13} \mathrm{C}_{\mathrm{CO} 2 \text {-calcite }}=-12.3\right.$ at $12^{\circ} \mathrm{C}$; Bottinga, 1969). By combining these fractionation factors, the following equation can be deduced: $\delta^{13} \mathrm{C}_{\mathrm{CH} 4}=\delta^{13} \mathrm{C}_{\mathrm{MDAC}}-4 \pm 6$. The $\delta^{13} \mathrm{C}$ values of methane calculated from this equation range from $-75.6 \pm 6 \%$ to $-55.6 \pm 6 \%$ (Table 2 ). The lowest estimates of $\delta^{13} \mathrm{C}$ values of methane are in very good agreement with the $\delta^{13} \mathrm{C}$ values of methane $(-72.7$ to 66.1\%o) measured from the in situ sampling of fluids at the same dive sites during the Gazcogne2 cruise (Ruffine et al., 2014). The highest estimates of $\delta^{13} \mathrm{C}$ values of methane might indicate that there could be some variability through time of the methane source with a possible contribution of thermogenic methane, or that there was an additional ${ }^{13} \mathrm{C}$-rich DIC source mixed with the ${ }^{13} \mathrm{C}$-depleted DIC resulting from AOM. The in situ fluids have almost pure methane gas composition with $\delta^{13} \mathrm{C}$ and $\delta \mathrm{D}$ values indicating that recent methane is purely biogenic and exclude the possible contribution of thermogenic methane (Ruffine et al., 2014). The contribution of another DIC source to the DIC pool from which the authigenic carbonates precipitated appears therefore more realistic, notably in the context of submarine groundwater discharge on the Aquitaine Shelf. 


\section{ACCEPTED MANUSCRIPT}

5-5 Methane seepage and submarine groundwater discharge on the Aquitaine Shelf

The oxygen and carbon isotopic compositions of the authigenic carbonates of the Aquitaine Shelf are the clues to characterize the sources of fluids from which they have precipitated. In fact, the $\delta^{18} \mathrm{O}-\delta^{13} \mathrm{C}$ values of the authigenic carbonates are distributed within a mixing zone between two end members, a ${ }^{18} \mathrm{O}$-rich- ${ }^{13} \mathrm{C}$-poor end member and a ${ }^{18} \mathrm{O}$-poor- ${ }^{13} \mathrm{C}$-rich end member, which variable relative contributions control the isotopic composition of authigenic carbonates (Fig. 9).

The ${ }^{18} \mathrm{O}$-rich- ${ }^{13} \mathrm{C}$-poor end member represents methane-derived authigenic carbonates (MDAC) composed of mixtures of calcite, aragonite and dolomite that would have precipitated in seawater with the LGM to present-day conditions, from DIC derived from AOM with the present-day in situ methane composition (postulating that this composition was not different during LGM). These theoretical $\delta^{18} \mathrm{O}-\delta^{13} \mathrm{C}$ values of MDAC cover a wide domain of variations $\left(+1.8<\delta^{18} \mathrm{O} \% 0<+6.7 ;-74.7<\delta^{13} \mathrm{C} \%<-56.1\right)$ that is calculated for the oxygen isotopic equilibrium of the three carbonate minerals (from equations $3,4,5)$ and for the whole range of carbon isotope fractionation during AOM (using the equation $\delta^{13} \mathrm{C}_{\mathrm{MDAC}}=\delta^{13} \mathrm{C}_{\mathrm{CH} 4}+4 \pm 6$ ).

The ${ }^{18} \mathrm{O}$-poor- ${ }^{13} \mathrm{C}$-rich end member corresponds to the carbonate that would precipitate with groundwater (GWC). In the North Aquitaine Basin the groundwater of the Eocene aquifer displays different $\delta^{18} \mathrm{O}$ values and temperatures with respect to their age (Jirakova et al., 2009, Saltel et al., 2013), with higher $\delta^{18} \mathrm{O}$ values and temperatures (-5.5\%o, $\left.12^{\circ} \mathrm{C}\right)$ observed during recent times as compared to the LGM $\left(-7.5 \%, 7^{\circ} \mathrm{C}\right)$. These values are used to calculate the range of $\delta^{18} \mathrm{O}$ values of GWC precipitated during recent times ($4.4 \%,-3.6 \%,-0.6 \%)$ and during LGM times $(-5.3 \% 0,-4.5 \%,-1.6 \%)$ for calcite, aragonite and dolomite respectively. The $\delta^{13} \mathrm{C}$ values of DIC of groundwater of the Northern Aquitaine basin are only available for the Coniacian-Turonian aquifer from the right bank of the Gironde estuary with lower values in modern groundwater $(-12 \%)$ than in the older groundwaters (-6.7\%o) of the last deglaciation (Jirakova et al., 2009). These characteristics of DIC of groundwater are used to estimate the $\delta^{13} \mathrm{C}$ values of GWC by considering the very small isotopic fractionation during carbonate precipitation (Emrich et al., 1970) at $12^{\circ} \mathrm{C}$ during recent times $\left(-11.7 \%\right.$ ) and at $7^{\circ} \mathrm{C}$ during the last deglaciation $(-6.7 \%$ ). 


\section{ACCEPTED MANUSCRIPT}

The two sources of pore fluids that have been identified to drive the carbonate diagenesis at the methane seeping sites of the Aquitaine Shelf have not only different isotopic compositions but they have also different geochemical characteristics (seawater vs freshwater), which would probably exert a major control on the mineralogical composition of authigenic carbonates as well as on geochemical reactions including dissolutionprecipitation as well as redox reactions affecting other mineral components of the sediment. However, the lack of chemical measurements of pore waters does not presently allow to go further in the discussion.

The vigorous methane flux currently seeping from the Aquitaine Shelf not only promotes aragonite precipitation by active AOM within the sediment zone, but also escapes as free gas bubbles from the seafloor to the water column (Dupré et al. 2014a, b). The sediment-bottom water boundary represents a very active zone where methane is oxidized to $\mathrm{CO}_{2}$ by methanotrophic bacteria during the Aerobic Oxidation of Methane $(\mathrm{AeOM})$, this process being largely enhanced by the strong bioturbation irrigating the seafloor sediment with oxygenated bottom seawater.

$$
\begin{aligned}
& \mathrm{CH}_{4}+2 \mathrm{O}_{2}->\mathrm{CO}_{2}+2 \mathrm{H}_{2} \mathrm{O}(8) \\
& \mathrm{CO}_{2}+\mathrm{CaCO}_{3}+\mathrm{H}_{2} \mathrm{O}->2 \mathrm{HCO}_{3}^{-}+\mathrm{Ca}^{2+}(9)
\end{aligned}
$$

The AeOM reaction (equation 8) produces $\mathrm{CO}_{2}$ that is responsible for dissolution of the solid carbonate previously precipitated (equation 9). The importance of this carbonate dissolution depends both on the methane and oxygen fluxes that are controlled by the intensity of $\mathrm{AeOM}$ and bioturbation rates. The carbonate crusts of the Aquitaine Shelf have been clearly submitted to the $\mathrm{AeOM}$ process as indicated by the numerous dissolution cavities on aragonite crystals identified by SEM observations.

\section{6- Conclusions}

The authigenic carbonate mounds associated to seafloor methane emissions that were recently discovered on the Aquitaine Shelf present characteristics overall similar to many cold seep systems: their very low $\delta^{13} \mathrm{C}$ values indicate that they are the product of microbial anaerobic oxidation of biogenic methane (AOM), and the mineral composition is a mixture of aragonite, calcite and dolomite. However, these shallow water depth seeps differ significantly from the deep-sea cold seeps because they are closely linked to the continental groundwater system where the coastal aquifer discharges DIC-rich freshwaters 


\section{ACCEPTED MANUSCRIPT}

offshore 10's km beyond the sea level position. The Aquitaine Shelf system displays strong similarities with the northern US Atlantic Margin where widespread active methane emissions have been discovered at water depths between 50 and $1700 \mathrm{~m}$, the upper shelf seeps being connected to groundwater system responsible for freshwater discharge to the seafloor more than $100 \mathrm{~km}$ away from the coastline (Cohen et al., 2010, Skarke et al., 2014).

On the Aquitaine Shelf (and the northern US Atlantic Shelf), the methane seeps are located at the shelf break. In the case of the US Atlantic Shelf, the source of methane was inferred to come from gas hydrates decomposition due to warming of intermediate waters at this depth, which would thus correspond to the upper limit of gas hydrates stability (Skarke et al. 2014). However, such an explanation can be ruled out in the case of the Aquitaine Shelf since gas hydrates are absent on this margin where methane is generated within the sedimentary deposits. Differently, it is proposed that the coincidence of the methane emissions at the shelf break indicates that it is the place where seawater is recharged whereas freshwater is discharged at the seafloor. The dynamics of these fluid flows is probably modulating (at least in part) methane emissions and authigenic carbonate precipitation.

\section{Acknowledgements}

The oceanographic expeditions Gazcogne1 (http://dx.doi.org/10.17600/13020070) and Gazcogne2 (http://dx.doi.org/10.17600/13030090) as well as the GAZCOGNE study were co-funded by TOTAL and IFREMER as part of the PAMELA (Passive Margin Exploration Laboratories) scientific project.

\section{References}

Aloisi, G., Pierre, C., Rouchy, J.M., Foucher, J.P., Woodside, J., the Medinaut Scientific Party, 2000. Methane-related authigenic carbonates of eastern Mediterranean Sea mud volcanoes and their possible relation to gas hydrate destabilisation. Earth Planet. Sci. Lett. 184:231-338.

Alperin, M.J., Reeburg, W.S., Whiticar, M.J., 1988. Carbon and hydrogen isotope fractionation resulting from anaerobic methane oxidation. Global Biogeochem. Cycles 2(3): 279-288. 


\section{ACCEPTED MANUSCRIPT}

Balthasar, U., Cusack, M., 2015. Aragonite-calcite seas - Quantifying the gray area. Geology 43-2:99-102. doi:10.1130/G36293.1

Bayon, G., Henderson, G.M., Bohn, M., 2009. U-Th stratigraphy of a cold seep carbonate crust. Chem. Geol. 260:47-56. doi:10.1016/j.chemgeo.2008.11.020

Bayon, G., Dupré, S., Ponzevera, E., Etoubleau, J., Chéron, S., Pierre, C., Mascle, J., Boetius, A., De Lange, G., 2013. Formation of carbonate chimneys in the Mediterranean Sea linked to deep-water oxygen depletion. Nature Geosci. 6:755-760. doi:10.1038/ngeo1888

Bellec, V.K., Cirac, P., 2010. Internal architecture of the soft sediment cover of the SouthAquitaine Shelf (Bay of Biscay): A record of high frequency sea level variations? C. R. Geosc. 342:79-86.

Biteau, J.-J., A. Le Marrec, M. Le Vot, J.-M. Masset, 2006. The Aquitaine Basin, Petrol. Geosci., 12 (3), 247-273, doi: 10.1144/1354-079305-674

Boetius, A., Ravenschlag, K., Schubert, C.J., Rickert, D., Widdel, F., Gieseke, A., Amann, R., Jorgensen, B.B., Witte, U., Pfannkuche, O., 2000. A marine consortium apparently mediating anaerobic oxidation of methane. Nature 407:623-626.

Bottinga, Y., 1969. Calculated fractionation factors for carbon and hydrogen isotope exchange in the system calcite- $\mathrm{CO}_{2}$-graphite-methane-hydrogen and water vapor. Geochim. Cosmochim. Acta 33:49-64.

Burnett, W.C., Bokuniewicz, H., Huettel, M., Moore, W.S., Taniguchi, M., 2003. Groundwater and pore water inputs to the coastal zone. Biogeochemistry 66:3-33.

Cirac, P., Berné, S., Castaing, P., Weber, O., 2000. Processus de mise en place et d'évolution de la couverture sédimentaire superficielle de la plate-forme nord-aquitaine. Oceanol. Acta 23:663-686.

Claypool G.E., Threlkeld C.N., 1983. Anoxic diagenesis and methane generation in sediments of the Blake Outer Ridge, Deep Sea Drilling Project Site 533, Leg 76. In: Sheridan R.E., Gradstein F.M. et al. (Eds.), Init. Repts. DSDP, 76, U.S. Govt. Printing Office, Washington. Pp. 391-402. 


\section{ACCEPTED MANUSCRIPT}

Cohen, D., Person, M., Wang, P., Gable, C.W., Hutchinson, D., Marksamer, A., Dugan, B., Kooi, H., Groen, K., Lizarralde, D., Evans, R.L., Day-Lewis, F.D., Lane, Jr J.W., 2010. Origin and Extent of Fresh Paleowaters on the Atlantic Continental Shelf, USA. Groundwater, 48 (1):143-158.

Craig, H., 1957. Isotopic standards for carbon and oxygen and correction factors for massspectrometric analysis of carbon dioxide. Geochim. Cosmochim. Acta 12:133-149.

Crémière, A., Pierre, C., Blanc-Valleron, M.M., Zitter, T., Cagatay, N.M., Henry, P., 2012. Methane-derived authigenic carbonates along the North Anatolian fault system in the Sea of Marmara (Turkey). Deep Sea Res. I 66:114-130.

De Choudens-Sanchez, V., Gonzalez, L.A., 2009. Calcite and aragonite precipitation under controlled instantaneous supersaturation: Elucidating the role of $\mathrm{CaCO}_{3}$ saturation state and $\mathrm{Mg} / \mathrm{Ca}$ ratio on calcium carbonate polymorphism. Jour. Sedim. Res. 79:363-376. doi:10.2110.jsr.2009.043

Dupré, S., Berger, L., Le Bouffant, N., Scalabrin, C., Bourillet, J.F., 2014a. Fluid emissions at the Aquitaine Shelf (Bay of Biscay, France): A biogenic origin or the expression of hydrocarbon leakage? Cont. Shelf Res. 88:24-33. doi: http://dx.doi.org/10.1016/j.csr.2014.07.004

Dupré, S., Loubrieu, B., Scalabrin, C., Ehrhold, A., Gautier, E., Ruffine, L., Pierre, C., Battani, A., Le Bouffant, N., Berger, L., 2014b. Discovery of widespread biogenic methane emissions and authigenic carbonate mound-like structures at the Aquitaine Shelf (Bay of Biscay). AGU fall meeting, San Francisco, 15-19 December 2014, abstract session OS12A-04.

Dupré, S., Mascle, J., Foucher, J.P., Harmegnies, F., Woodside, J., Pierre, C., 2014c. Warm brine lakes in craters of active mud volcanoes, Menes caldera off NW Egypt: evidence for deep-rooted thermogenic processes. Geo-Mar. Lett. 34:153-168. doi $10.1007 / \mathrm{s} 00367-014-0367-1$

Emrich, K., Ehhalt, D.H., Vogel, J.C., 1970. Carbon isotope fractionation during the precipitation of calcium carbonate. Earth Planet. Sci. Lett. 8: 363-371. 


\section{ACCEPTED MANUSCRIPT}

Foucher, J.P., Westbrook, G.H., Boetius, A., Ceramicola, S., Dupré, S., Mascle, J., Mienert, J., Pfannkuche, O., Pierre, C., Praeg, D., 2009. Structure and drivers of cold seep ecosystems: an overview from HERMES results. Oceanography 22-1:92-109.

Fritz, P., Smith, D.G.W., 1970. The isotopic composition of secondary dolomites. Geochim. Cosmochim. Acta 34:1161-1173.

Goldsmith, J.R., Graf, D.L., Herad, H.C., 1961. Lattice constants of the calciummagnesium carbonates. Am. Mineral. 46:453-457.

Gonfiantini, R., Stichler, W., Kozanski, K., 1995. Standards and intercomparison materials distributed by the International Atomic Energy Agency for stable isotope measurements. In : Reference and Intercomparison Materials for Stable Isotopes of Light Elements, IAEA-TECDOC-825. IAEA, Vienna, pp 13-29.

Grossman, E.L., Ku, T.L., 1986. Carbon and oxygen isotope fractionation in biogenic aragonite: temperature effects. Chem. Geol. 59:59-74.

Hathaway, J.C., Poag, C.W., Valentine, P.C., Miller, R.E., Schultz, D.M., Manheim, F.T., Kohout, F.A., Bothner, M.H., Sangrey, D.A., 1979. U.S. Geological Survey core drilling on the Atlantic Shelf. Science: 206, 4418, 515-527. doi:10.1126/science.206.4418.515

Himmler T., Brinkmann F., Bohrmann G., Peckmann J., 2011. Corrosion patterns of seepcarbonates from the eastern Mediterranean Sea. Terra Nova $23: 206-212$.

Jirakova, H., Huneau, F., Celle-Jeanton, H., Hrkal, Z., Le Coustumer, P., 2009. Paleorecharge conditions of the deep aquifers of the Northern Aquitaine region (France). J. Hydrol. 368:1-16.

Judd, A., Hovland, M., 2007. Seabed fluid flow. The impact on Geology, Biology, and the Marine Environment. Cambridge University Press, pp 475.

Kim, S.T., O’Neil, J.R., 1997. Equilibrium and nonequilibrium oxygen isotope effects in synthetic carbonates. Geochim. Cosmochim. Acta 61(16): 3461-3475.

Liebetrau, V., Eisenhauer, A., Linke, P., 2010. Cold seep carbonates and associated coldwater corals at the Hikurangi Margin, New Zealand: new insights into fluid pathways, growth structures and geochronology. Mar. Geol. 272: 307-317. doi:10.1016/j.margeo.2010.01.003 


\section{ACCEPTED MANUSCRIPT}

Luff, R., Wallmann, K., Aloisi, G., 2004. Numerical modeling of carbonate crust formation at cold vent sites: significance for fluid and methane budgets and chemosynthetic biological communities. Earth Planet. Sci. Lett. 221:337-353. Doi:10.1016/10012$821 \times(04) 00107-4$

Malone, M.J., Claypool, G., Martin, J.B., Dickens, G.R., 2002. Variable methane fluxes in shallow marine systems over geologic time. The composition and origin of pore waters and authigenic carbonates on the New Jersey shelf. Mar. Geol. 189:175-196.

Moore, W.S., 1999. The subterranean estuary: a reaction zone of ground water and sea water. Mar. Chem. 65:111-125.

Morse, J.W., Wang, Q., Tsio, M.Y., 1997. Influence of temperature and Mg:Ca ratio on $\mathrm{CaCO}_{3}$ precipitates from seawater. Geology 25:85-87. doi:10.1130/0091-7613

Naehr, T.H., Rodriguez, N.M., Bohrmann, G., Paull, C.K., Botz, R., 2000. Methanederived authigenic carbonates associated with gas hydrate decomposition and fluid venting at the Blake Ridge Diapir. In: Proceedings of the Ocean Drilling Program. Scientific Results, 164, 285-300.

Nöthen, K., Kasten, S., 2011. Reconstructing changes in seep activity by means of pore water and solid phase $\mathrm{Sr} / \mathrm{Ca}$ and $\mathrm{Mg} / \mathrm{ca}$ ratios in pockmark sediments of the Northern Congo Fan. Mar. Geol. 287:1-13. doi:10.1016/j.margeo.2011.06.008

Peckmann, J., Reimer, A., Luth, U., Luth, C., Hansen, B.T., Heinicke, C., Hoefs, J., Reitner, J., 2001. Methane derived carbonates and authigenic pyrite from the northwestern Black Sea. Mar. Geol. 177:129-150.

Peltier, W.R., Fairbanks, R.G., 2006. Global glacial ice volume and Last Glacial Maximum duration from an extended Barbados sea level record. Quat. Sci. Rev. 25:3322-3337. doi:10.1016/j.quascirev.2006.04.010

Pierre, C., Bayon, G., Blanc-Valleron, M.M., Mascle, J., Dupré, S., 2014a. Authigenic carbonates related to active seepage of methane-rich hot brines at the Cheops mud volcano, Menes caldera (Nile deep-sea fan, eastern Mediterranean Sea). Geo-Mar. Lett. 34:253-267. Doi 10.1007/s00367-014-0362-6 


\section{ACCEPTED MANUSCRIPT}

Pierre, C., Blanc-Valleron, M.M., Dupré, S., 2014b. Methane-derived authigenic carbonates from the upper continental margin of the Bay of Biscay (France). AGU fall meeting, San Francisco, 15-19 December 2014, abstract session OS21A-1099.

Ruffine, L., Battani, A., Bignon, L., Croguennec, C., Caprais, J.C., Birot, D., Bayon, G., Lantéri, N., Levaché, D., Dupré, S., 2014. Natural gas seepage along the edge of the Aquitaine Shelf (France). Origin and flux measurements. AGU fall meeting, San Francisco, 15-19 December 2014, abstract session OS21A-1097d'.

Saltel, M., Franceschi, M., Lavielle, B., Thomas, B., 2013. Caractérisation de la paléorecharge des aquifères du nord du Bassin Aquitain par l'utilisation de traceurs isotopiques et des gaz rares. In: Dix neuvièmes journées techniques du Comité Français d'Hydrogéologie de l'Association Internationale des Hydrogéologues. Bordeaux, 30 mai- 2 juin 2013: 75-83.

Skarke, A., Ruppel, C., Kodis, M., Brothers, D., Lobecker, E., 2014. Widespread methane leakage from the sea floor on the northern US Atlantic margin. Nature Geosc. 7:657-661. doi:10.1038/NGEO2232

Tarutani, T., Clayton, R.N., Mayeda, T.K., 1969. The effect of polymorphism and magnesium substitution of oxygen isotope fractionation between calcium carbonate and water. Geochim. Cosmochim. Acta 33:987-996.

Teichert, B.M.A., Eisenhauer, A., Bohrmann, G., Haase-Schramm, A., Bock, B., Linke, P., 2003. U/Th systematics and ages of authigenic carbonates from Hydrate Ridge, Cascadia Margin: Recorders of fluid flow variations. Geochim. Cosmochim. Acta 67:3845-3857.

Van Geldern, R., Hayashi, T., Böttcher, M.E., Mottl, M.J., Barth, J.A.C., Stadler, S., 2013. Stable isotope geochemistry of pore waters and marine sediments from the New Jersey shelf: Methane formation and fluid origin. Geosphere 9, 1, 96-112. doi:10.1130/GES00859.1

Waelbroeck, C., Labeyrie, L., Michel, E., Duplessy, J.C., McManus, J.F., Lambeck, K., Balbon, E., Labracherie, M., 2002. Sea-level and deep water temperature changes derived from benthic foraminifera isotopic records. Quat. Sci. Rev. 21:295-305.

Wehrmann L.M., Risgaard-Petersen N., Schrum H.N., Walsh E.A., Huh Y., Ikehara M., Pierre C., D’Hondt S., Ferdelman T.C., Ravelo A.C., Takahashi K., Alvarez-Zarikian C., 


\section{ACCEPTED MANUSCRIPT}

IODP Exp. 323 Scientific Party, 2011. Coupled organic and inorganic carbon cycling in the deep subseafloor sediment of the northeastern Bering Sea Slope (IODP Exp. 323). Chem. Geol. 284, 251-261

Whiticar, M.J., 1999. Carbon and hydrogen isotope systematics of bacterial formation and oxidation of methane. Chem. Geol. 161:291-314.

Whiticar, M.J., Faber E., 1986. Methane oxidation in sediments and water column environments-isotopic evidence. Org. Geochem. $10: 759-768$.

Figure 1: Bathymetry of the studied zone of the Aquitaine Shelf and location of the sites of sampling during the Gazcogne1 cruise (box-cores) and the Gazcogne 2 cruise (ROV dives). The background bathymetric data have been derived from the EMODnet Bathymetry portal- http://www.emodnet.bathymetry.eu

Figure 2: Seafloor pictures from ROV dives of the Gazcogne2 cruise. A: site A (dive 536); B: site D (dive 535) - sample GZ2-535-CC02; C: site D (dive 535); D: site G- sample GZ2-537-CC01

Figure 3: Macrofacies of the carbonate crusts collected during the ROV dive 535 (site D) of the Gazcogne2 cruise (A: 535-CC01 ; B: 535-CC02 ; C: 535-CC03 ; D: 535-CC04).

Figure 4: Macrofacies of the carbonate crusts collected during the ROV dive 536 (site A) of the Gazcogne2 cruise (A: 536-CC01; B: 536-CC02).

Figure 5: Macrofacies of the carbonate crusts collected during the ROV dive 537 (site G) of the Gazcogne2 cruise (A: 537-CC01 ; B: 537-CC03 ; C: 537-CC04 ; D: 537-CC02 ; E : 537-CC05).

Figure 6: Mineralogical composition of the carbonate fraction (in relative wt $\%$ of the total carbonate) of carbonate crusts and concretions collected during the Gazcogne1 and Gazcogne2 cruises on the Aquitaine Shelf. 
ACCEPTED MANUSCRIPT

Figure 7: SEM photographs (backscatter imagery) of the carbonate crusts collected during the Gazcogne2 cruise on the Aquitaine Shelf. (A: GZ2-535-CC03 = authigenic aragonite cementing detrital grains. B: GZ2-535-CC03 = close-up view of the circular cavities (white arrows) corresponding to moulds of gas bubbles in the authigenic aragonite cement. C: GZ2-537-CC02 = authigenic aragonite cementing detrital quartz grains and a foraminifer ; numerous circular cavities corresponding to moulds of gas bubbles. D: GZ2537-CC02 $=$ authigenic aragonite as palisade cement (white arrows) and infilling the pores among detrital grains).

Figure 8: SEM photographs (backscatter imagery) of the carbonate crusts collected during the Gazcogne2 cruise on the Aquitaine Shelf. (A: GZ2-535-CC01 = authigenic aragonite crystals cementing detrital grains of quartz and feldspar ; framboids and isolated crystals of pyrite appear with a high reflectivity. B: GZ2-537-CC03 = close-up view of aragonite crystals with numerous dissolution cavities (black arrows). C: GZ2-537-CC02 = close-up view of dolomite cement (white arrows) formed by rounded aggregates of platy crystals. D: GZ2-535-CL12-3/5 cm = Mixture of rosettes and isolated rhombs of Mg-calcite (white arrows) and of aragonite elongated crystals).

Figure 9: Distribution of the $\delta^{18} \mathrm{O}$ et $\delta^{13} \mathrm{C}$ values of the authigenic carbonates of the Aquitaine Shelf. The $\delta$ values measured in the bulk carbonate (black filled square) and the aragonite cement (black open square) are compared to the $\delta$ values of the Methane Derived Authigenic Carbonate (MDAC) fraction of each sample calculated by subtracting the carbonate fraction of sediment (blue filled diamond). The theoretical $\delta$ values of the MDAC end-member have been calculated for the carbonate minerals (calcite, aragonite, dolomite) that precipitated with the bottom-water conditions during the period from the modern-Interglacial to the Last Glacial Maximum (IG and G respectively), during AOM with variable isotopic fractionation (Alperin et al., 1988) and in situ $\delta^{13} \mathrm{C}$ values for methane (Ruffine et al., 2014). The theoretical $\delta$ values of the GroundWater Carbonate (GWC) end-member have been calculated for the carbonate minerals (calcite, aragonite, dolomite) precipitated with the groundwater conditions during modern-Interglacial to Last Glacial Maximum times (Jirakova et al., 2009; Saltel et al., 2013). 
Table 1: Macrofacies description, SEM observations, mineralogy of the carbonate fraction, oxygen and isotopic composition of the bulk carbonate and aragonite cement of the samples (carbonate crusts and concretions, soft sediment, bivalve shells) collected during the Gazcogne1 and Gazcogne2 cruises on the Aquitaine Shelf.

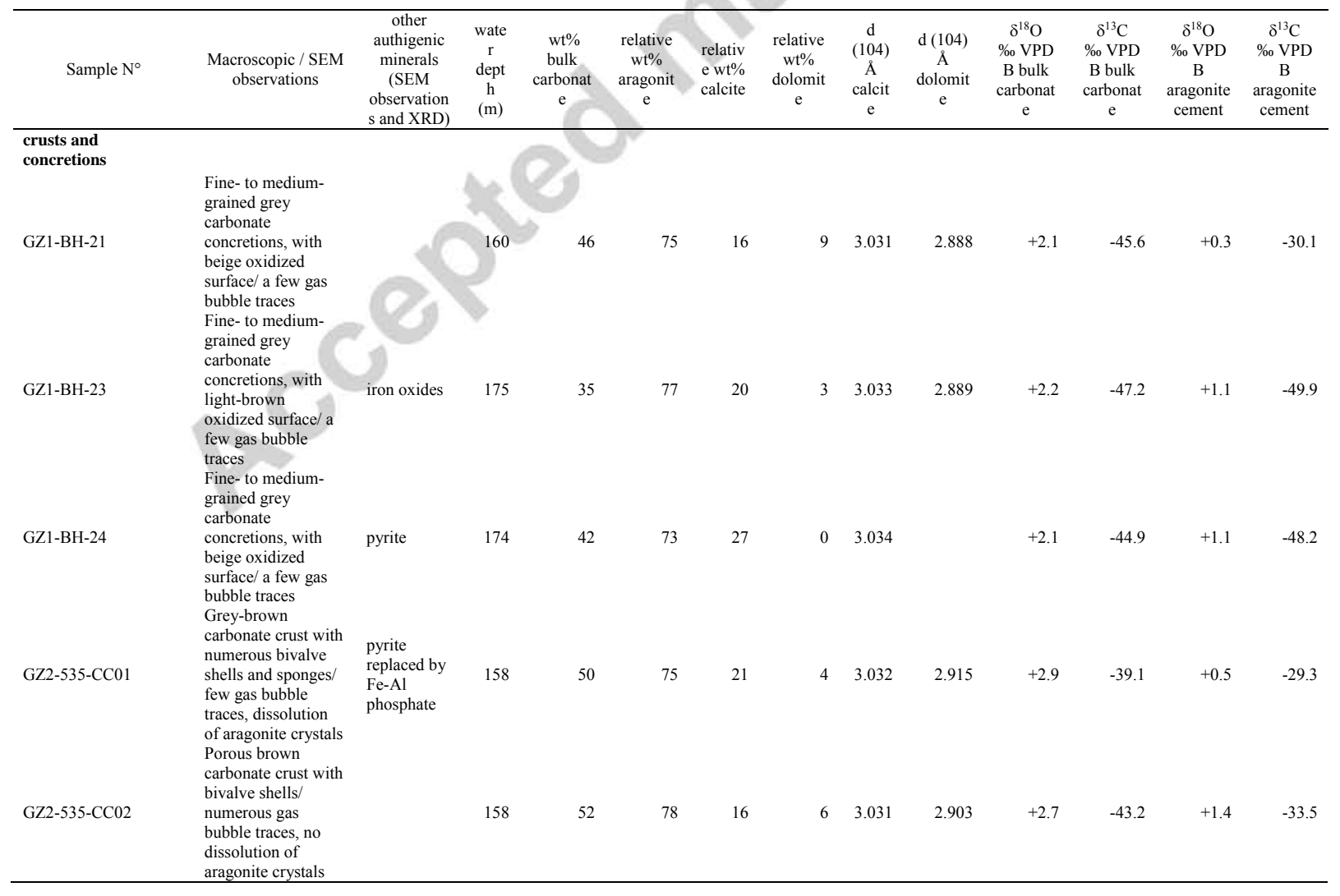




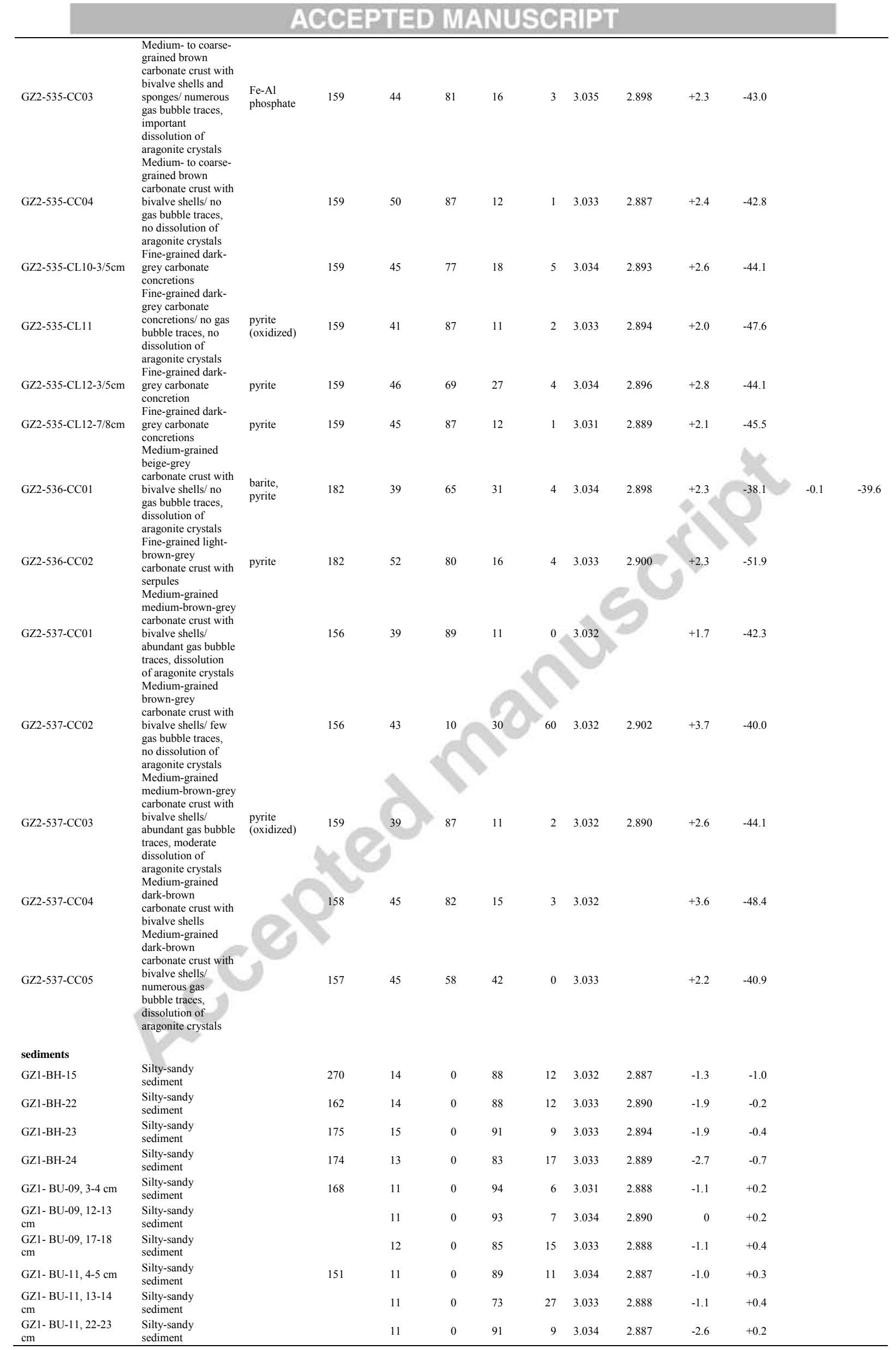


ACCEPTED MANUSCRIPT

\begin{tabular}{|c|c|c|c|c|c|c|c|c|c|c|}
\hline GZ1- BU-12, 4-5 cm & $\begin{array}{l}\text { Silty-sandy } \\
\text { sediment }\end{array}$ & 210 & 7 & 0 & 82 & 18 & 3.034 & 2.887 & -1.1 & +0.2 \\
\hline GZ1- BU-12, 9-10 cm & $\begin{array}{l}\text { Silty-sandy } \\
\text { sediment }\end{array}$ & & 7 & 0 & 100 & 0 & 3.034 & 2.886 & -1.6 & +0.3 \\
\hline $\begin{array}{l}\text { GZ1- BU-12, 17-18 } \\
\mathrm{cm}\end{array}$ & $\begin{array}{l}\text { Silty-sandy } \\
\text { sediment }\end{array}$ & & 7 & 0 & 90 & 10 & 3.034 & 2.887 & -1.0 & +0.2 \\
\hline GZ1- BU-13, 4-5 cm & silty sandy sediment & 273 & 11 & 0 & 95 & 5 & 3.034 & 2.888 & -2.2 & 0 \\
\hline GZ1- BU13, 18-19 cm & $\begin{array}{l}\text { Silty-sandy } \\
\text { sediment }\end{array}$ & & 11 & 0 & 97 & 3 & 3.034 & 2.888 & -1.1 & +0.2 \\
\hline \multicolumn{11}{|l|}{ bivalve shells } \\
\hline GZ1-BU-11, 22-23 cm & & 151 & & & & & & & +2.1 & +0.8 \\
\hline
\end{tabular}

Table 2: Estimations of the $\delta^{18} \mathrm{O}$ and $\delta^{13} \mathrm{C}$ values of the Methane Derived Authigenic Carbonate fraction (f MDAC) of the carbonate crusts and concretions of the Aquitaine Shelf and of the $\delta^{13} \mathrm{C}$ values of methane, assuming a single source of DIC in pore water from AOM.

\begin{tabular}{|c|c|c|c|c|c|c|c|c|c|c|}
\hline sample & $\begin{array}{c}\delta^{18} \mathrm{O} \\
\% \text { VPD } \\
\mathrm{B} \text { bulk } \\
\text { carbonat } \\
\mathrm{e} \\
\text { (measur } \\
\text { ed) }\end{array}$ & $\begin{array}{c}\delta^{13} \mathrm{C} \\
\% \text { VPD } \\
\text { B bulk } \\
\text { carbonat } \\
\text { e } \\
\text { (measur } \\
\text { ed) }\end{array}$ & $\begin{array}{l}\text { wt } \% \\
\text { carbon } \\
\text { ate }\end{array}$ & $\begin{array}{l}\text { relativ } \\
\text { e wt } \% \\
\text { aragon } \\
\text { ite }\end{array}$ & $\begin{array}{c}\text { relati } \\
\text { ve } \\
\text { wt } \% \\
\text { calcit } \\
\text { e }\end{array}$ & $\begin{array}{l}\text { relativ } \\
\text { e wt } \% \\
\text { dolomi } \\
\text { te }\end{array}$ & $\begin{array}{l}\text { f MDAC } \\
\text { (calculat } \\
\text { ed) }\end{array}$ & $\begin{array}{c}\delta^{18} \mathrm{O} \\
\% \text { VPD } \\
\text { B } \\
\text { MDAC } \\
\text { (calculat } \\
\text { ed) }\end{array}$ & $\begin{array}{c}\delta^{13} \mathrm{C} \% \\
\text { VPDB } \\
\text { MDAC } \\
\text { (calcula } \\
\text { ted) }\end{array}$ & $\begin{array}{c}\delta^{13} \mathrm{C} \% \\
\mathrm{VPDB} \\
\mathrm{CH}_{4} \\
\text { (calculat } \\
\text { ed) } \\
\text { (average } \\
\pm 6 \text { ) }\end{array}$ \\
\hline $\begin{array}{l}\text { GZ1- } \\
\text { BH21 }\end{array}$ & +2.1 & -45.6 & 46 & 75 & 16 & 9 & 0.74 & +3.3 & -61.8 & -65.8 \\
\hline $\begin{array}{l}\text { GZ1- } \\
\text { BH23 }\end{array}$ & +2.2 & -47.2 & 35 & 77 & 20 & 3 & 0.66 & +4.2 & -71.6 & -75.6 \\
\hline $\begin{array}{l}\text { GZ1- } \\
\text { BH24 } \\
\text { GZ2- }\end{array}$ & +2.1 & -44.9 & 42 & 73 & 27 & 0 & 0.71 & +3.6 & -63.1 & -67.1 \\
\hline $\begin{array}{l}535- \\
\text { CC01 }\end{array}$ & +2.9 & -39.1 & 50 & 75 & 21 & 4 & 0.76 & +4.3 & -51.6 & -55.6 \\
\hline $\begin{array}{l}\text { GZ2- } \\
535-\end{array}$ & +2.7 & -43.2 & 52 & & & & & & & \\
\hline $\begin{array}{l}\text { CC02 } \\
\text { GZ2- }\end{array}$ & & & & 78 & 16 & 6 & 0.77 & +3.9 & -56.3 & -60.3 \\
\hline $\begin{array}{l}535- \\
\text { CC03 } \\
\text { GZ2- }\end{array}$ & +2.3 & -43.0 & 44 & 81 & 16 & 3 & 0.72 & +3.7 & -59.2 & -63.2 \\
\hline $\begin{array}{l}535- \\
\mathrm{CC} 04\end{array}$ & +2.4 & -42.8 & 50 & 87 & 12 & 1 & 0.76 & +3.7 & -56.2 & -60.2 \\
\hline $\begin{array}{l}\text { GZ2- } \\
535- \\
\text { CL10- }\end{array}$ & +2.6 & -44.1 & 45 & & & & & & & \\
\hline $3 / 5 \mathrm{~cm}$ & & & & 77 & 18 & 5 & 0.73 & +4.1 & -60.2 & -64.2 \\
\hline
\end{tabular}




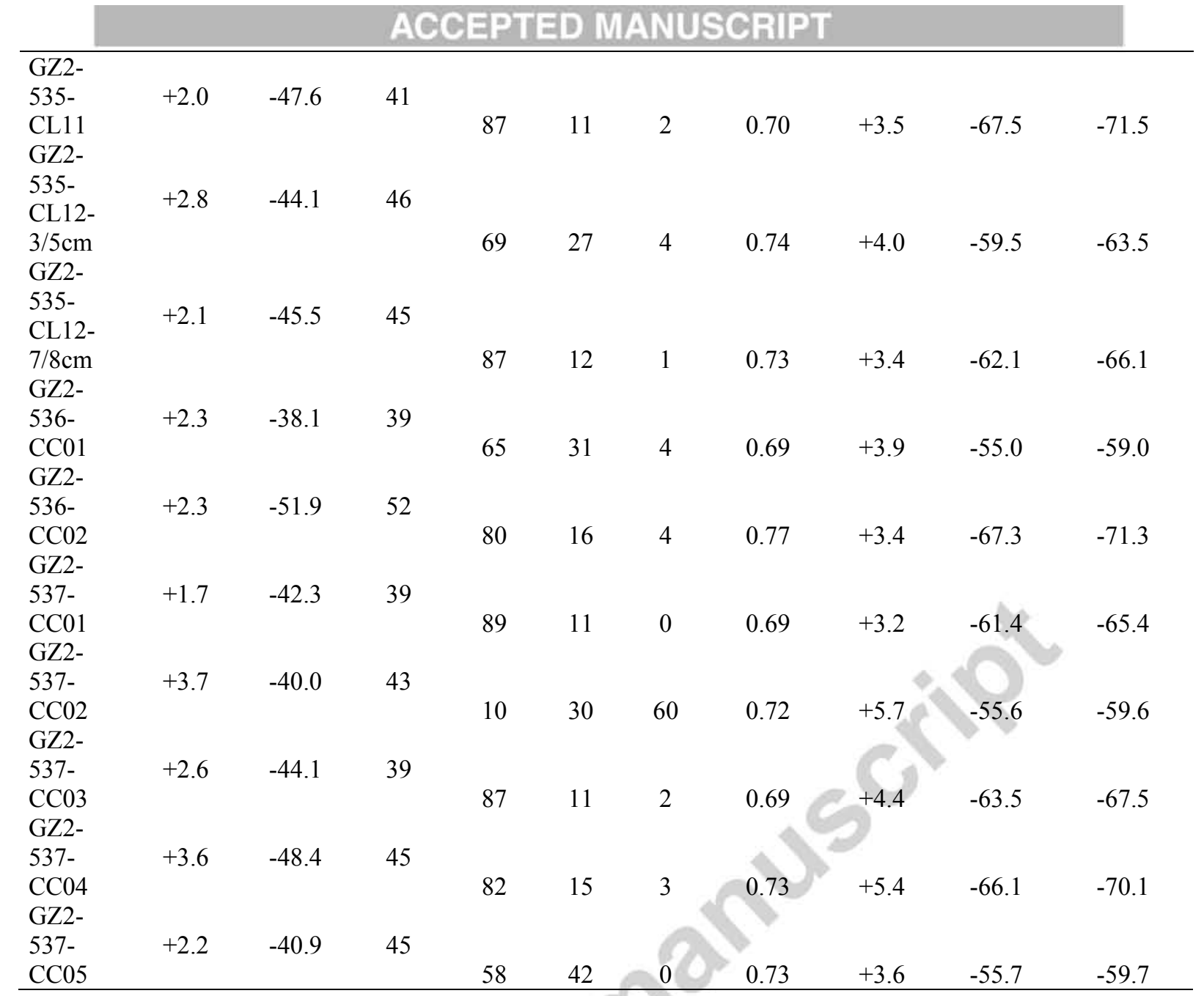

\section{Highlights}

- Authigenic carbonate crusts are related to methane seeps on the Aquitaine Shelf

- Anaerobic oxidation of methane was responsible for carbonate cementation

- Submarine groundwater discharge is mixed with seawater recharge at the shelf break 


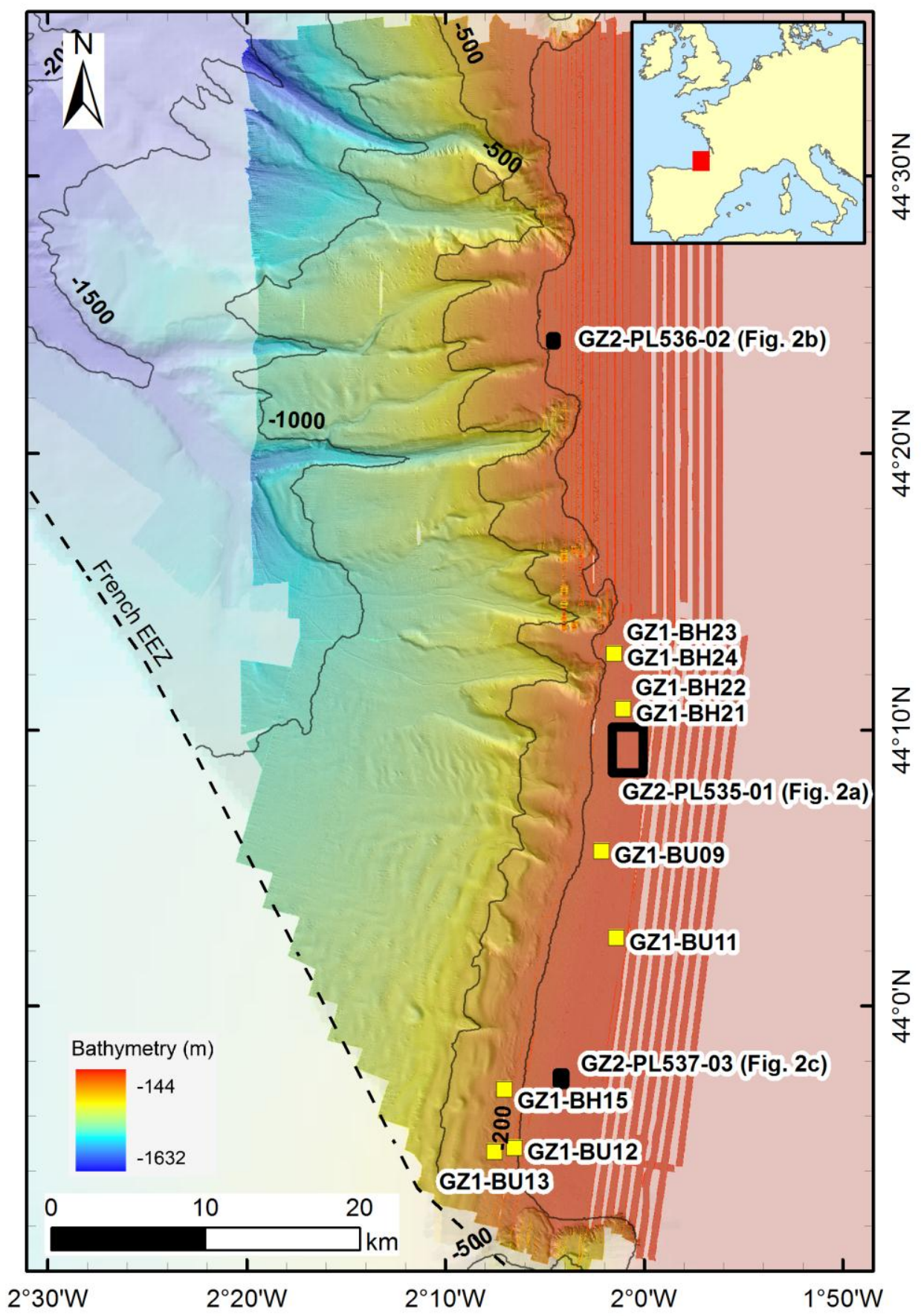



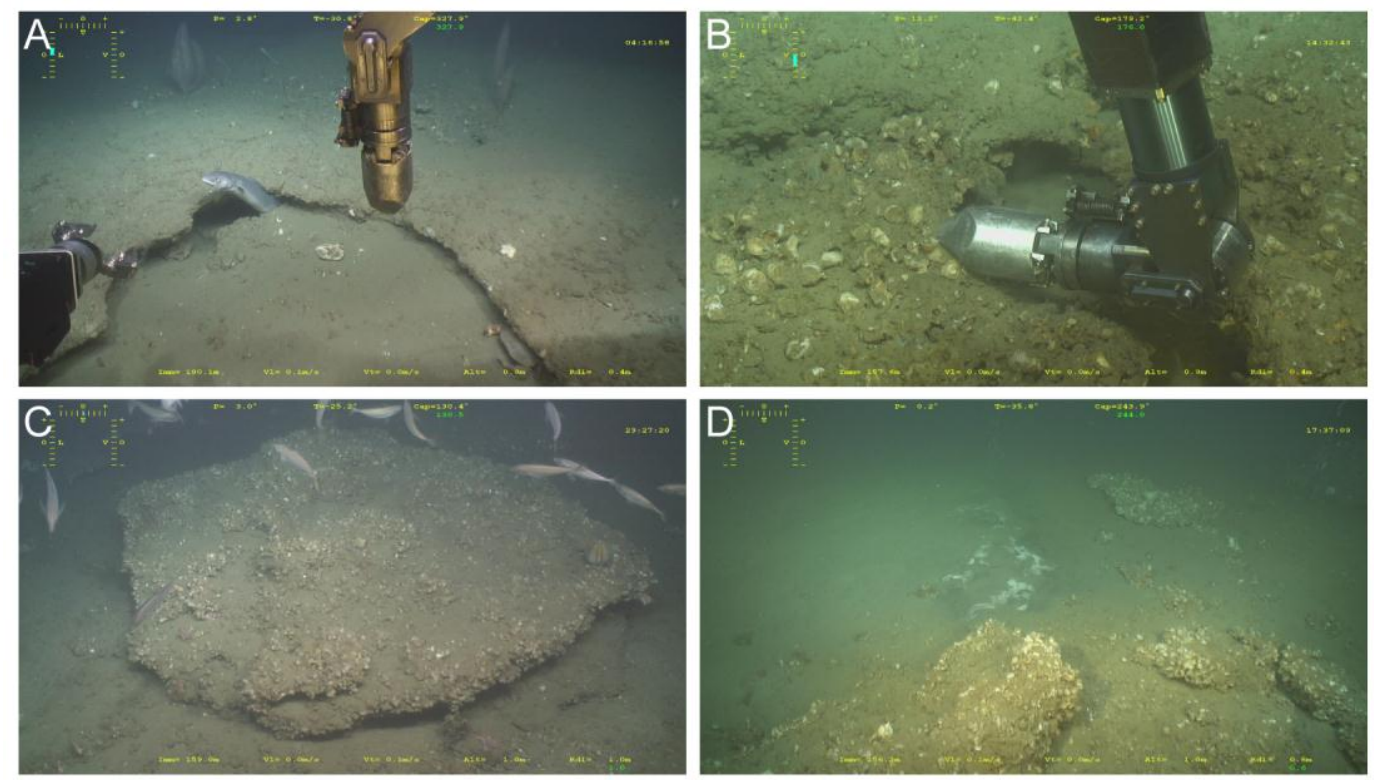

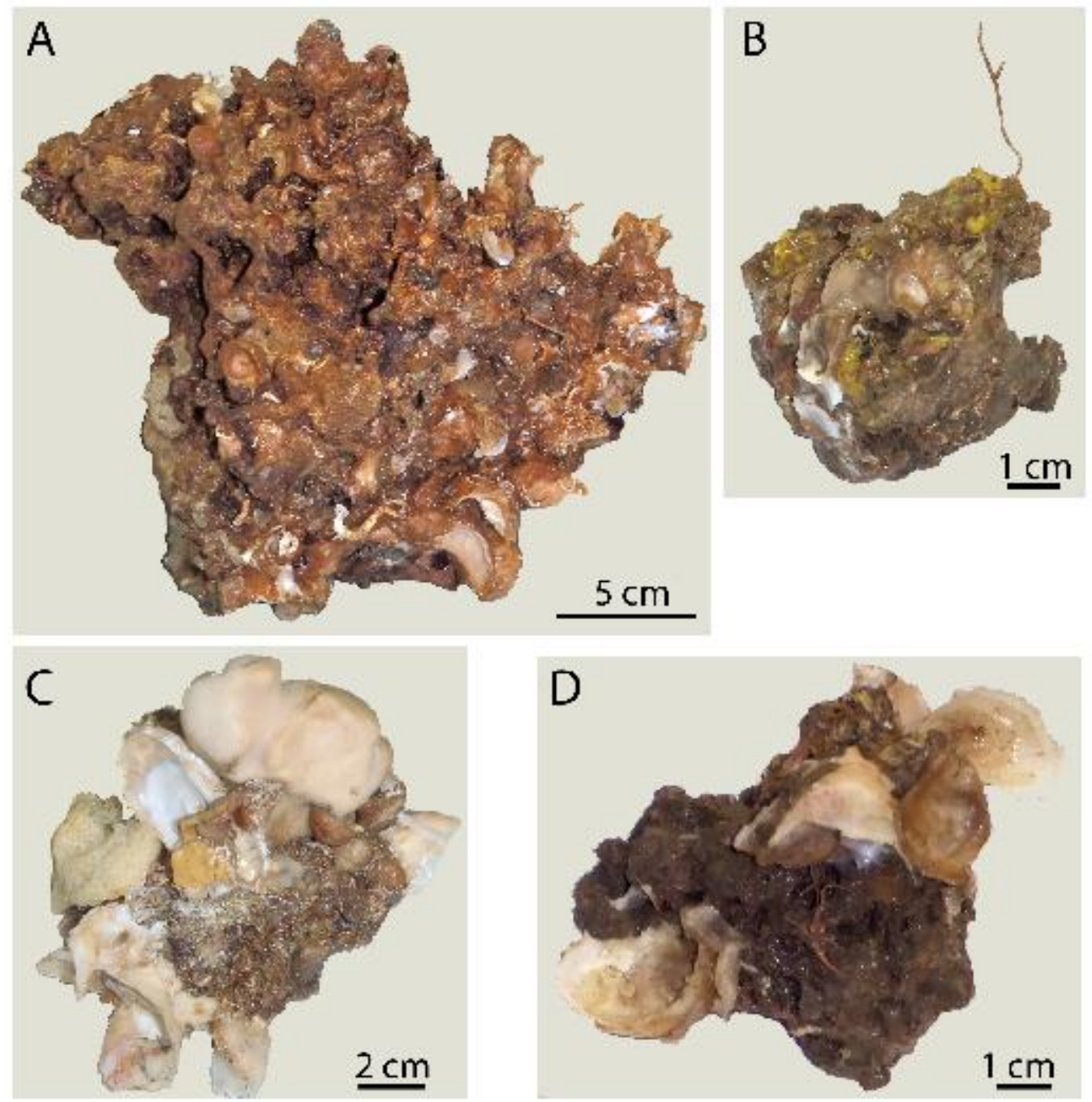

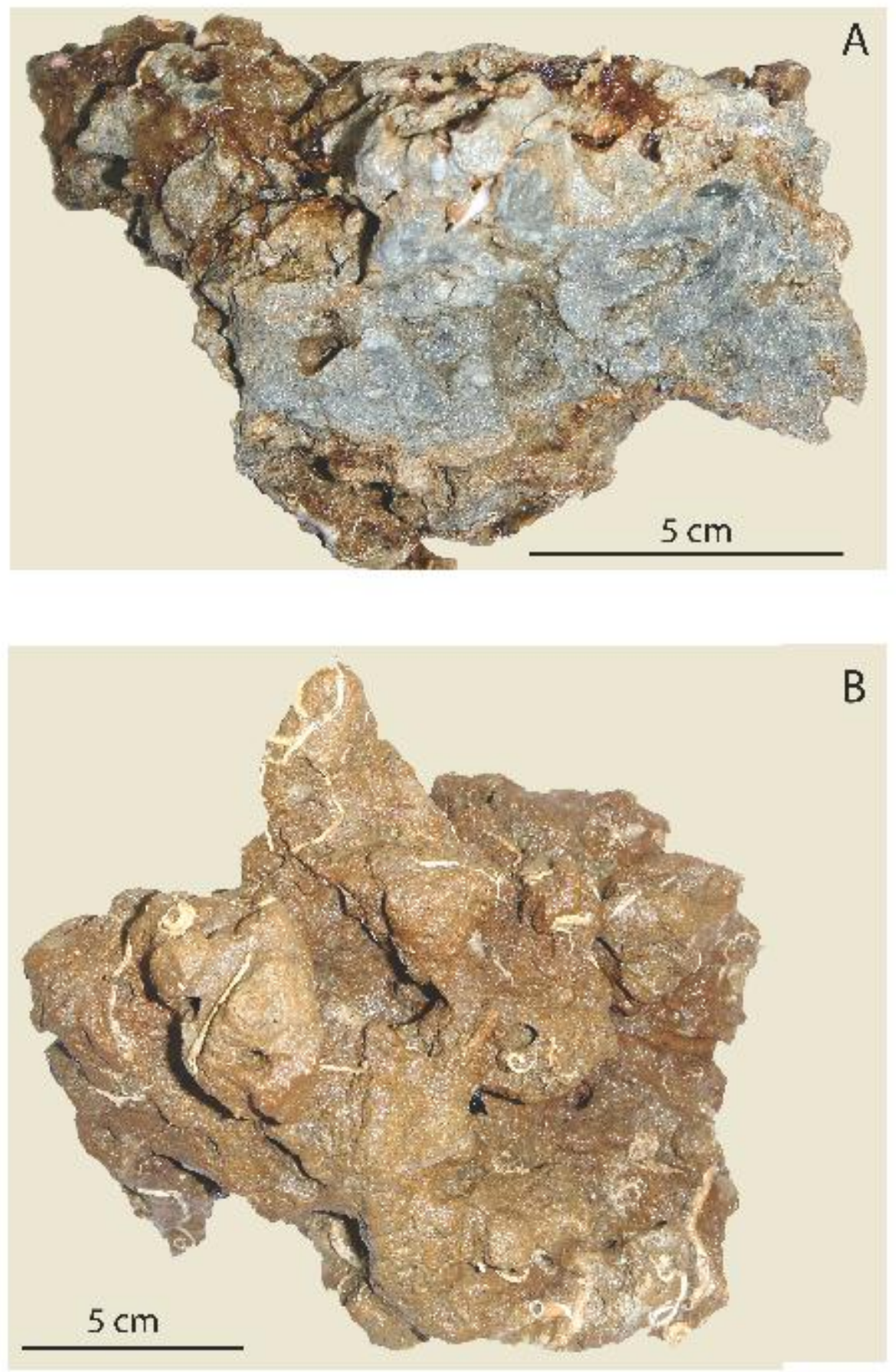


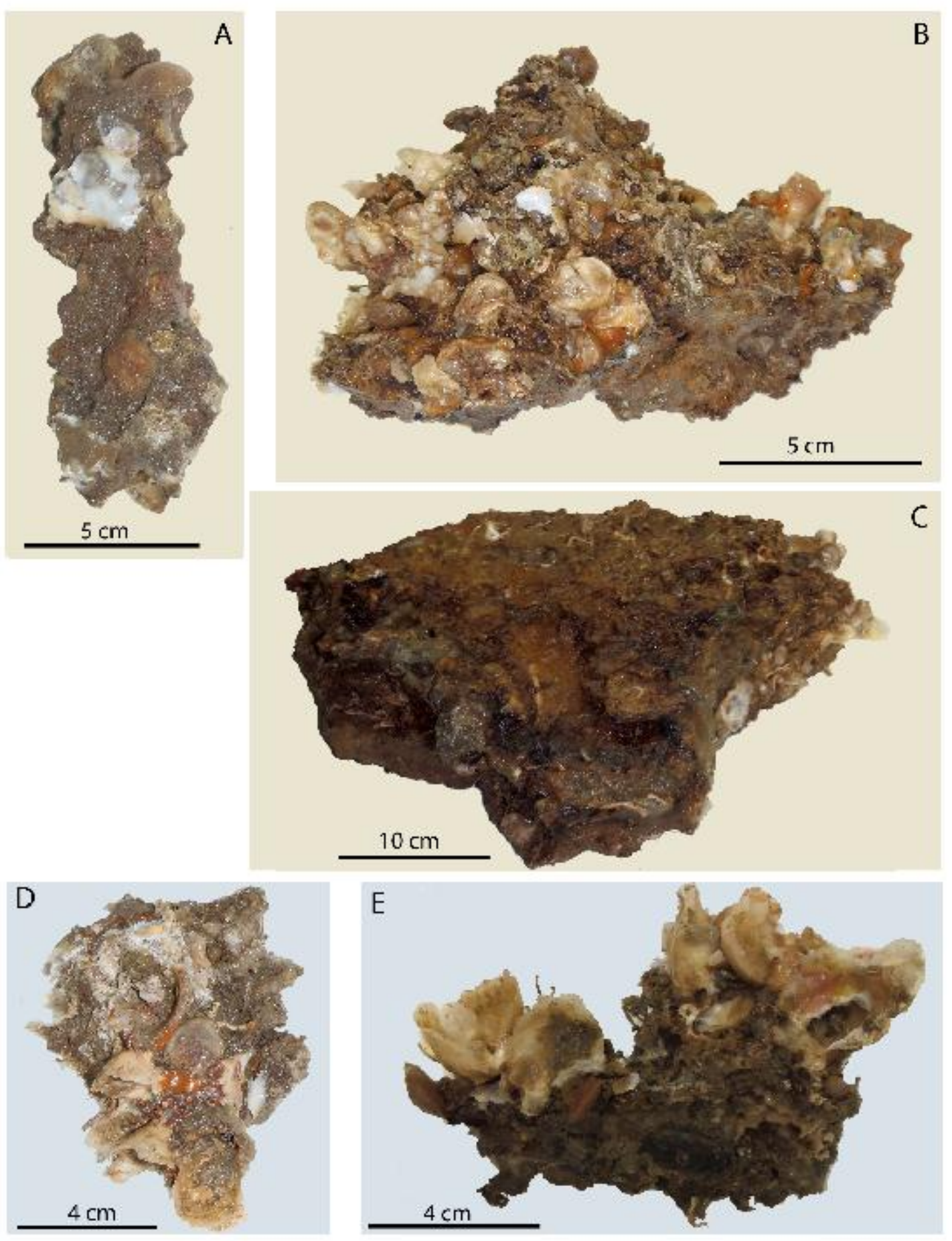




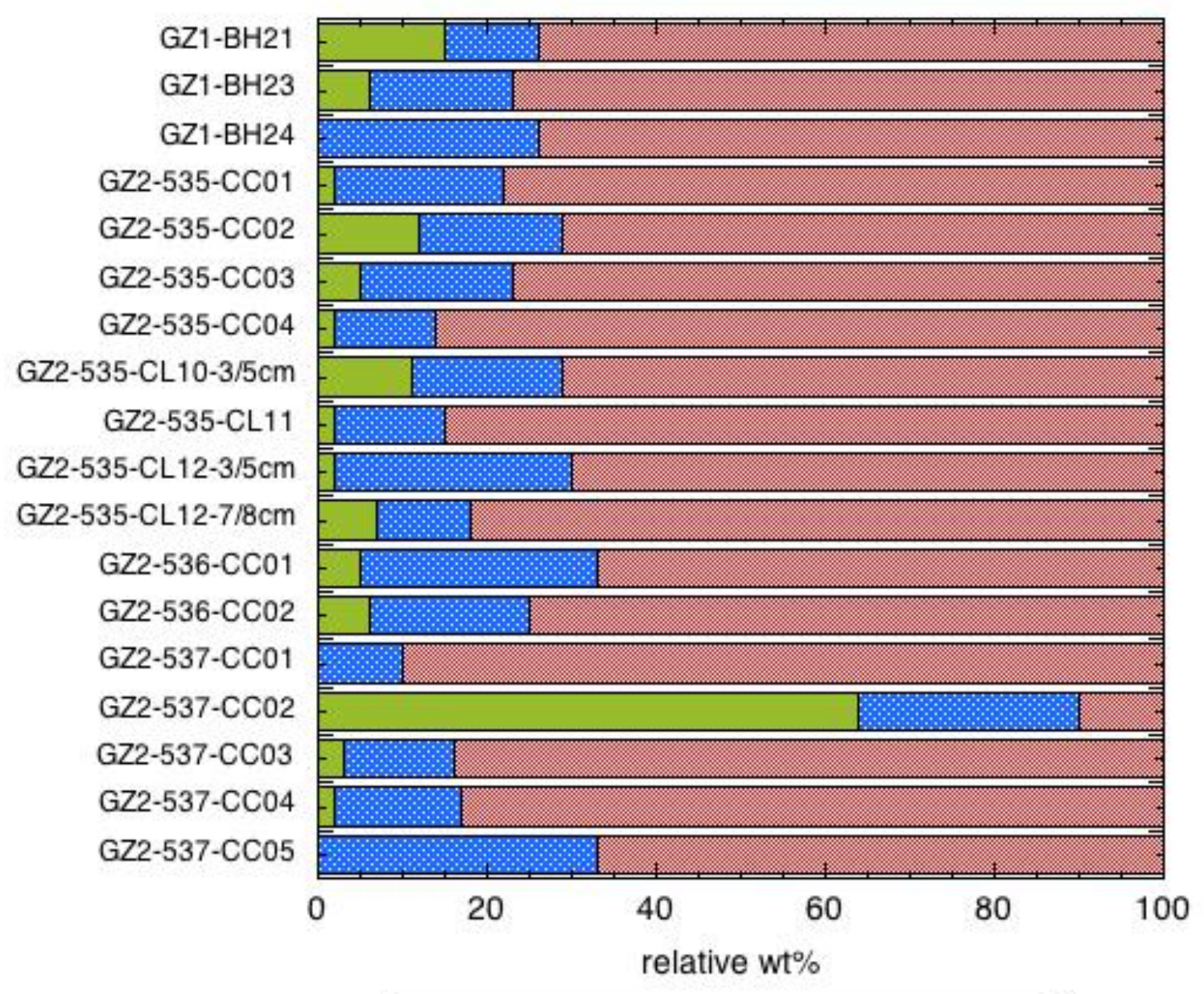

aragonite $\quad$ calcite $\square$ dolomite


ACCEPTED MANUSCRIPT
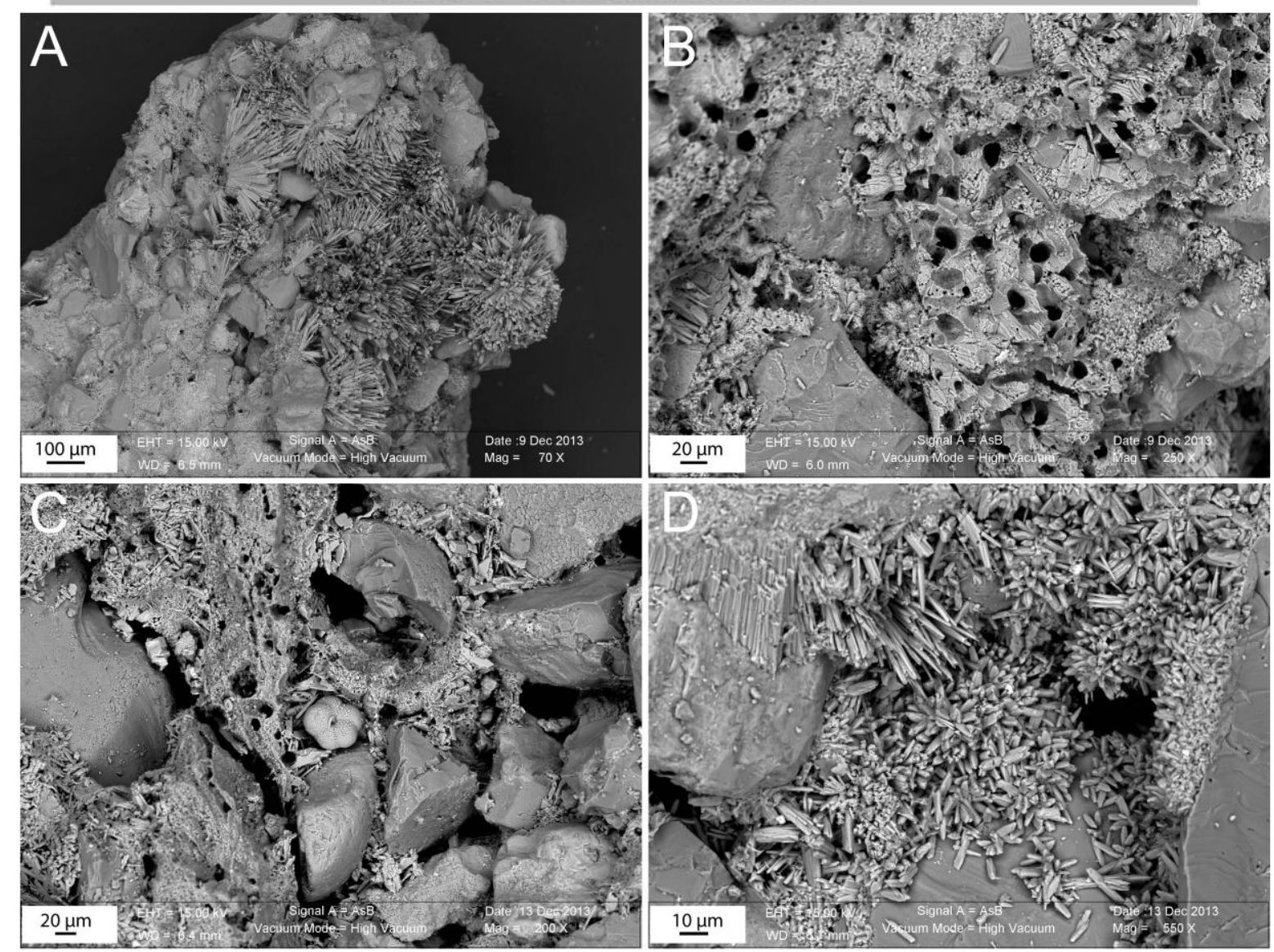

$10 \mu \mathrm{m}$ 

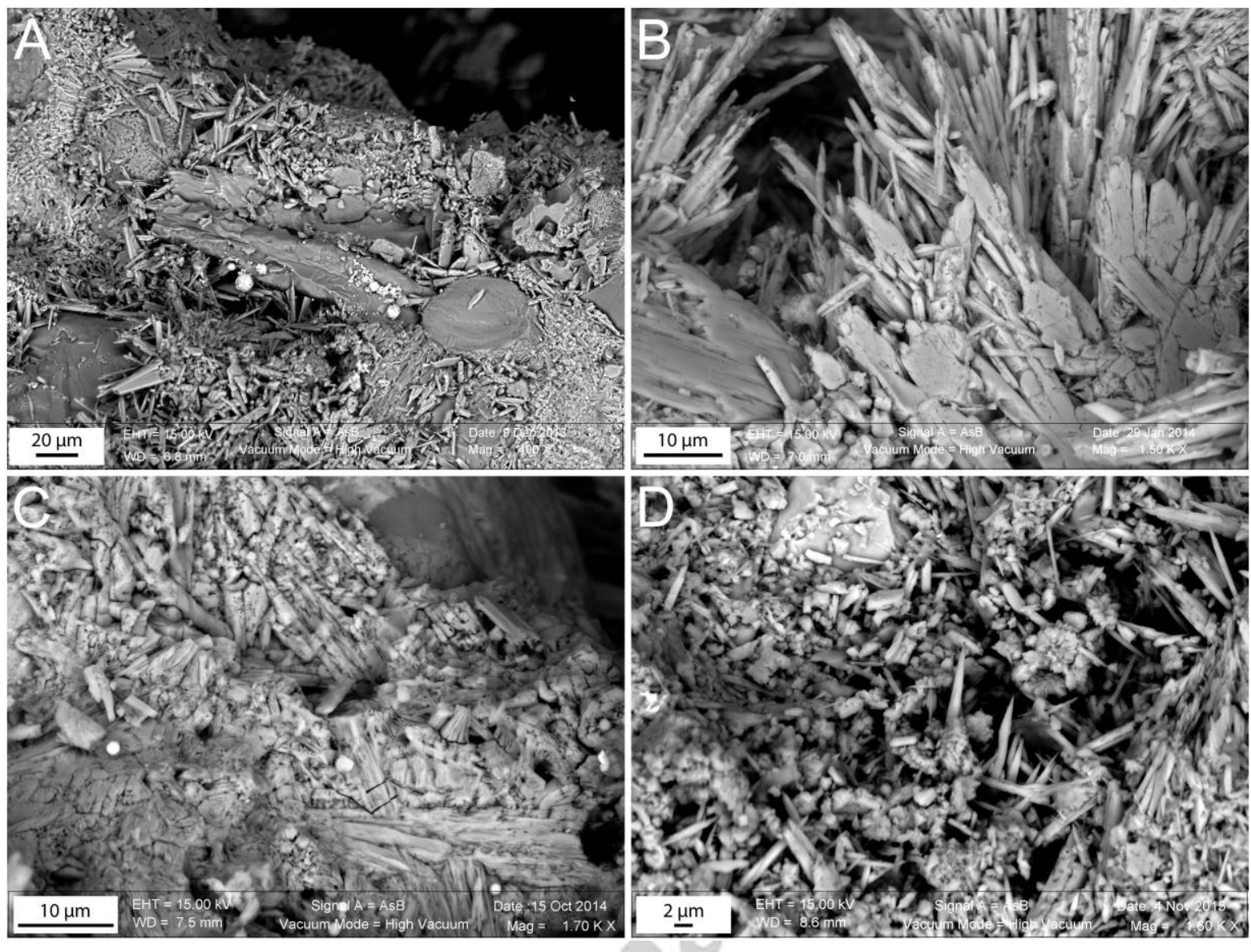


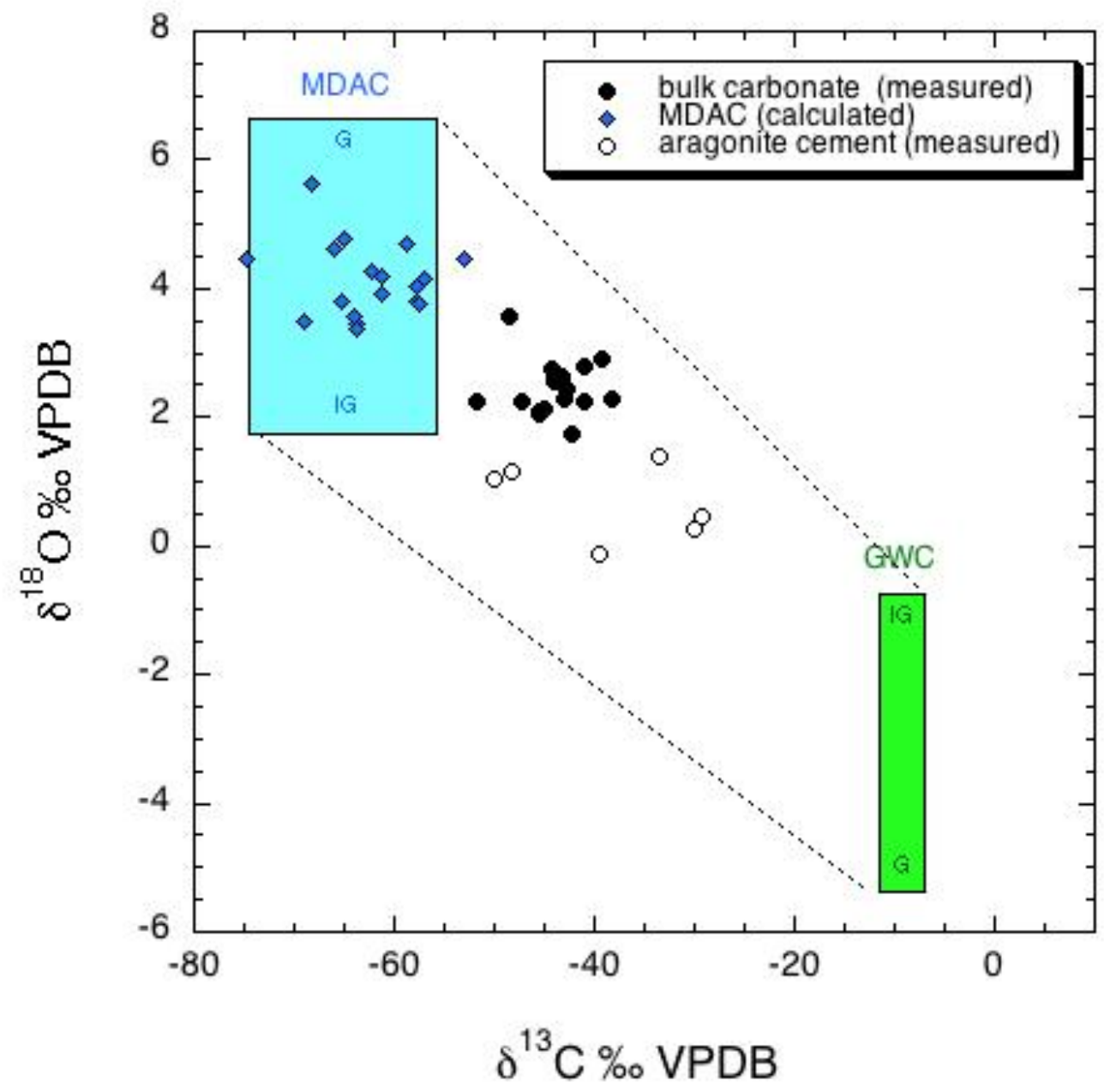

Pierre et al- revised manuscript Continental Shelf Research 